\title{
Lipid metabolism of phenol-tolerant Rhodococcus opacus strains for lignin bioconversion
}

\author{
William R. Henson ${ }^{1}$, Fong-Fu Hsu², Gautam Dantas $3,4,5,6$, Tae Seok Moon ${ }^{1 *}$ (D) and Marcus Foston ${ }^{1 *}$ (D)
}

\begin{abstract}
Background: Lignin is a recalcitrant aromatic polymer that is a potential feedstock for renewable fuel and chemical production. Rhodococcus opacus PD630 is a promising strain for the biological upgrading of lignin due to its ability to tolerate and utilize lignin-derived aromatic compounds. To enhance its aromatic tolerance, we recently applied adaptive evolution using phenol as a sole carbon source and characterized a phenol-adapted R. opacus strain (evol40) and the wild-type (WT) strain by whole genome and RNA sequencing. While this effort increased our understanding of the aromatic tolerance, the tolerance mechanisms were not completely elucidated.

Results: We hypothesize that the composition of lipids plays an important role in phenol tolerance. To test this hypothesis, we applied high-resolution mass spectrometry analysis to lipid samples obtained from the WT and evol40 strains grown in $1 \mathrm{~g} / \mathrm{L}$ glucose (glucose), $0.75 \mathrm{~g} / \mathrm{L}$ phenol (low phenol), or $1.5 \mathrm{~g} / \mathrm{L}$ phenol (high phenol, evol40 only) as a sole carbon source. This analysis identified $>100$ lipid species of mycolic acids, phosphatidylethanolamines (PEs), phosphatidylinositols (PIs), and triacylglycerols. In both strains, mycolic acids had fewer double bond numbers in phenol conditions than the glucose condition, and evol40 had significantly shorter mycolic acid chain lengths than the WT strain in phenol conditions. These results indicate that phenol adaptation affected mycolic acid membrane composition. In addition, the percentage of unsaturated phospholipids decreased for both strains in phenol conditions compared to the glucose condition. Moreover, the PI content increased for both strains in the low phenol condition compared to the glucose condition, and the PI content increased further for evol40 in the high phenol condition relative to the low phenol condition.
\end{abstract}

Conclusions: This work represents the first comprehensive lipidomic study on the membrane of R. opacus grown using phenol as a sole carbon source. Our results suggest that the alteration of the mycolic acid and phospholipid membrane composition may be a strategy of $R$. opacus for phenol tolerance.

Keywords: Rhodococcus opacus, Phenol, Triacylglycerol, Mycolic acid, Phospholipid, Mass spectrometry

\section{Background}

Lignocellulose is a potential source of renewable fuels, chemicals, and materials, but it requires efficient conversion for commercial viability [1-3]. Lignocellulose is composed primarily of cellulose, hemicellulose, and lignin [4]. Cellulose and hemicellulose can be easily

\footnotetext{
*Correspondence: tsmoon@wustl.edu; mfoston@wustl.edu 1 Department of Energy, Environmental and Chemical Engineering, Washington University in St. Louis, St. Louis, MO 63130, USA Full list of author information is available at the end of the article
}

depolymerized into sugars which can be converted via microbial fermentation to bioproducts $[3,5,6]$. However, lignin was designed by nature to give plants structural rigidity and to help plants resist biological attack, which makes industrial enzymatic or microbial depolymerization of lignin difficult $[7,8]$. A hybrid approach to lignin conversion has recently been proposed, which combines the rapid depolymerization kinetics of catalytic or thermochemical processing with the metabolic funneling and selective bioproduction capabilities of microbial systems [9-11]. In this approach, lignin is thermochemically 
or catalytically depolymerized into diverse aromatic compounds, which are then converted by microbes into a single stream of valuable bioproducts [12]. However, lignin-derived aromatic compounds are toxic to most microbes and can reduce product titers, yields, and productivities in the fermentation of lignocellulosic hydrolysates [13]. Efforts are underway to improve the aromatic tolerance of microbes used for fermentation of lignocellulose-derived sugars and to develop strains that have aromatic degradation pathways to convert ligninderived aromatics into valuable products [14-18].

Rhodococcus opacus PD630 (hereafter R. opacus) is an important microbial strain for bioproduction due to its inherently high aromatic tolerance and ability to consume many different aromatic compounds found in depolymerized lignin [19-24]. R. opacus is a Gram-positive actinomycete bacterium that can accumulate triacylglycerols (TAGs), a biodiesel precursor, up to $~ 78 \%$ of its cell dry weight when grown on sugars [25]. Moreover, with the newly developed synthetic biology tools [26-28], $R$. opacus could also be engineered for the bioconversion of lignin into many other bioproducts. While many studies have focused on characterizing the lipid metabolism of $R$. opacus for the goal of improving TAG accumulation [2932 ], it is unknown whether, or how, the lipid metabolism plays a role in the tolerance of aromatic compounds.

Cell membrane structure and composition are important for microbial stress tolerance. The cell membrane acts as a permeability barrier for the influx and efflux of different compounds, and microbes respond to stressful growth conditions by modifying the structure of their cell membrane [33, 34]. For example, different yeast strains change their cell membrane composition under solvent stress [35, 36], acid stress [37], and freezing or salt stress [38]. For tolerance to aromatic compounds such as toluene, Gram-negative bacteria such as Pseudomonas putida convert cis-double bonds to trans-double bonds on fatty acid chains, increase amounts of cyclopropane fatty acids, and modify phospholipid head groups [39-41].

Rhodococcus belongs to the Mycolata taxon that includes Corynebacterium, Mycobacterium, and Nocardia [42]. These bacteria have an unusually complex cell envelope compared to other Gram-positive bacteria (Fig. 1). For example, R. opacus has an outer membrane of mycolic acids (mycomembrane) [43-45] in addition to a phospholipid membrane $[46,47]$. Studies in Rhodococcus strains indicate that they decrease fatty acid chain lengths and increase the amount of branched chain fatty acids during growth using aromatic compounds [48, 49], and the presence of aromatic compounds has been shown to alter the composition of meromycolate chains of mycolic acid species [50-52]. However, changes in intact lipid species using soft ionization techniques have not been extensively studied in $R$. opacus grown using aromatic compounds as a sole carbon source, and their role in aromatic tolerance remains to be elucidated.

Mass spectrometry is a useful tool for measuring changes in lipid composition in response to aromatic compounds. Collision-induced dissociation (CID) multiple-stage high-resolution mass spectrometry (HRMS) provides detailed structural information which is essential for the identification of lipid species in nonmodel microbes [50]. In this work, we employed HR-MS together with liquid chromatography/mass spectrometry (LC/MS) to characterize cell membrane lipids, including mycolic acids and phospholipids, and biofuel target lipids, TAGs $[23,53]$. Our approach enables the determination of the total carbon number and double bond number that each intact lipid molecule has, while the approach using fatty acid methyl ester formation, followed by gas chromatography/mass spectrometry (GC/ MS) [32, 49], can provide only information regarding whole cell fatty acid compositions rather than intact lipid compositions. In this work, the total carbon number is defined as the number of carbons present on all three acyl chains of each TAG molecule, both acyl chains of each phospholipid molecule, and the meromycolate and alpha branches of each mycolic acid molecule. Similarly, the total double bond (DB) number is defined as the number of double bonds and cyclopropane units present on all acyl chains or all branches of the corresponding lipid molecule. Because both numbers are crucial to membrane fluidity [54], this analysis can provide valuable insights into their effects on aromatic tolerance.

Phenol is a lignin depolymerization product model compound that contains an aromatic ring and a hydroxyl group. It is present in a variety of depolymerized lignin streams at low concentrations [55-57]. Phenol, like many lignin-derived aromatic compounds, is hypothesized to disrupt cellular membranes due to the hydrophobicity of the aromatic ring [58]. It also has a toxicity level that is similar to many other lignin-derived aromatic compounds [59]. In this work, phenol was chosen as a lignin depolymerization product model compound for studying changes in membrane composition that were hypothesized to be correlated with evolutionary changes that led to improved lignin depolymerization product (i.e., phenol) tolerance and utilization [20]. Increasing lignin depolymerization product tolerance in $R$. opacus could improve biorefinery economics by increasing product titers, yields, and productivities for lignin valorization via a hybrid conversion approach.

To explore the relationship between lipid metabolism and aromatic tolerance in $R$. opacus, we characterized lipids from a phenol-adapted $R$. opacus strain (evol40) and the wild-type (WT) strain that used glucose 


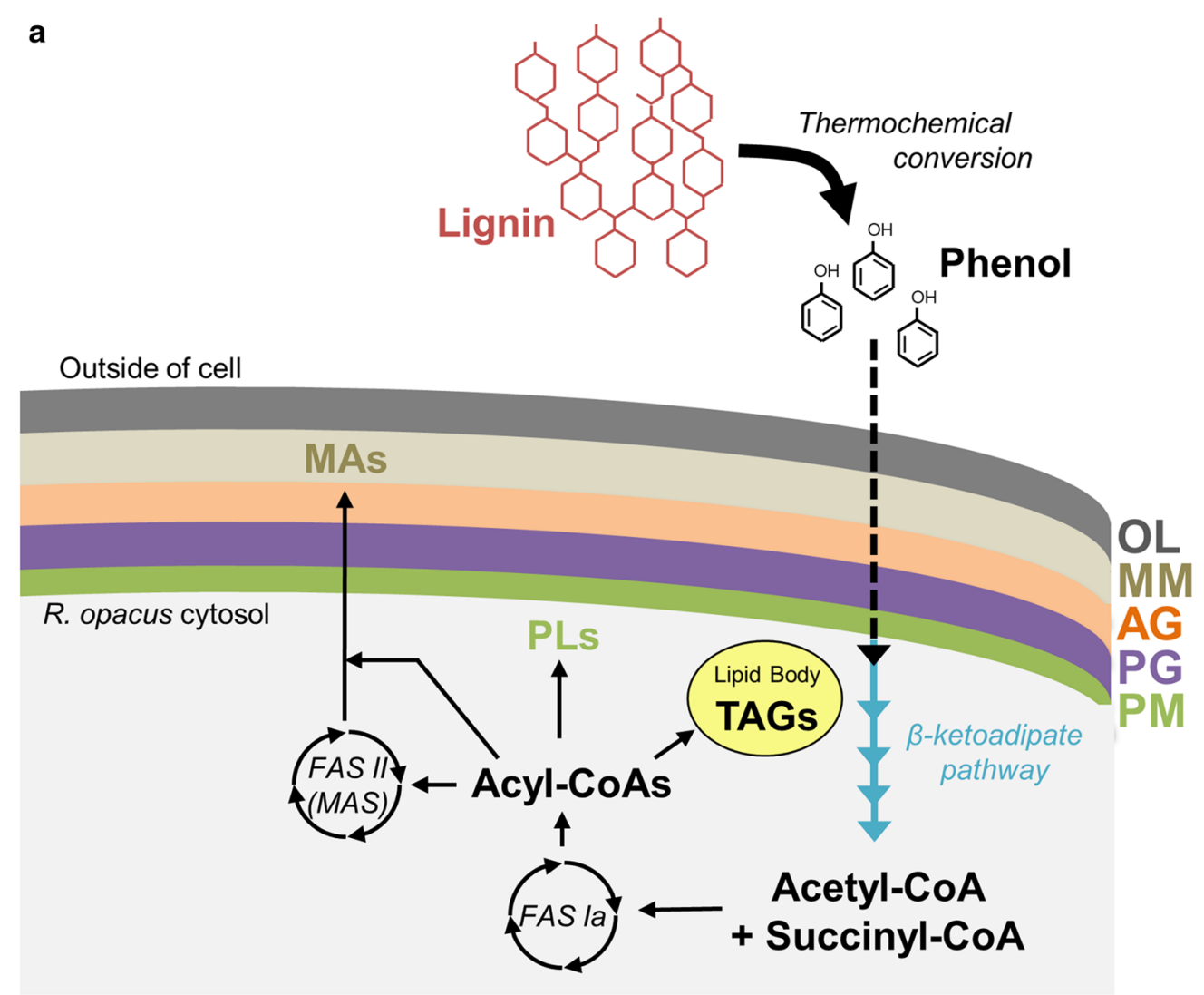

b

Mycolic acids

TAGs<smiles>[R]C(O)C([R2])C(=O)O</smiles>

a branch<smiles>[R]C(=O)OC[C@@H]([2H])COP(=O)(O)OC1C(O)C(O)C2C(O)C(O)C1C2O</smiles><smiles>[R]C(=O)OCCOC([R])=O</smiles>

Fig. 1 Conversion of phenol to lipids by R. opacus PD630. a Cell membrane structure and simplified model for conversion of a lignin monomer (phenol) to lipids by R. opacus PD630 [42]. Phenol is imported into the cell and converted to central metabolic intermediates acetyl-CoA and succinyl-CoA [20,72]. Next, acetyl-CoA is converted into acyl-CoAs by fatty acid synthase (FAS) la [32]. Phospholipids (PLs), triacylglycerols (TAGs), and a-branches of mycolic acids (MAs) are synthesized using acyl-CoAs from FAS la, while meromycolate branches for mycolic acids are synthesized by further chain elongation using other fatty acid synthases (FAS II) or mycocerosic acid synthases (MAS) [32]. Triacylglycerols can be stored in lipid droplets [30]. PM phospholipid membrane, PG peptidoglycan layer, AG arabinogalactan layer, MM mycomembrane, and OL outer layer. $\mathbf{b}$ Representative structures of lipid types examined in this work.

or phenol as a sole carbon source. evol40 was isolated from a culture that was serially passaged on increasing concentrations of phenol as a sole carbon source, and it demonstrated improved phenol tolerance and utilization in our previous work [20]. We hypothesized that (1) both the WT and evol40 strains would alter its lipid composition when grown using phenol compared to glucose as a sole carbon source, and (2) evol40 would have a different lipid composition from that of the WT strain when grown using phenol. We detected significant compositional changes in mycolic acids and phospholipids between strains during growth using phenol. Overall, this work provides new observations of the lipid metabolism of $R$. opacus during growth on a lignin depolymerization model compound and suggests a role of membrane lipid composition in phenol tolerance. 


\section{Methods}

\section{Cell cultures and lipid extraction}

Rhodococcus opacus PD630 (DSMZ 44193) was used as the WT strain for comparison to the phenol-adapted $R$. opacus strain evol40, which was generated and characterized in our previous work [20]. R. opacus strains were grown in a minimal salts medium that was adjusted to $\mathrm{pH}=7.0$ using $6 \mathrm{M} \mathrm{HCl}$ or $2 \mathrm{M} \mathrm{NaOH}$ and filter-sterilized using a $0.22-\mu \mathrm{m}$ filter [20]. Cells were prepared in the same growth conditions $\left(30^{\circ} \mathrm{C}, 250\right.$ r.p.m.) as RNASeq experiments as previously described [20]. Briefly, single colonies from LB plates were grown in $2 \mathrm{~mL}$ of minimal salts medium supplemented with $0.3 \mathrm{~g} / \mathrm{L}$ phenol and $1 \mathrm{~g} / \mathrm{L}$ ammonium sulfate as carbon and nitrogen sources, respectively, in a 50-mL glass culture tube for $48 \mathrm{~h}$. After $48 \mathrm{~h}$, the cell culture was subcultured in increasingly larger volumes of the $0.3 \mathrm{~g} / \mathrm{L}$ phenol minimal media to prepare enough cells for the initial inoculum (see [20] for more information). To start the main culture, cells were centrifuged at $3000 \mathrm{~g}$ for $10 \mathrm{~min}$ at room temperature, resuspended in a minimal salts medium without carbon or nitrogen sources, and added to $100 \mathrm{~mL}$ of minimal salts medium supplemented with $1 \mathrm{~g} / \mathrm{L}$ glucose (glucose), $0.75 \mathrm{~g} / \mathrm{L}$ phenol (low phenol), or $1.5 \mathrm{~g} / \mathrm{L}$ phenol (high phenol) as a sole carbon source and $0.05 \mathrm{~g} / \mathrm{L}$ ammonium sulfate as the nitrogen source at an initial $\mathrm{OD}_{600}$ of 0.3 . Cultures were grown to early stationary phase $\left(\mathrm{OD}_{600} \sim 1\right.$ for all cultures). The WT strain did not show significant growth ( $<1$ doubling after $48 \mathrm{~h}$ ) using $1.5 \mathrm{~g} / \mathrm{L}$ phenol as a sole carbon source in volumes larger than $10 \mathrm{~mL}$, so it was not included in our analysis.

Lipids were extracted from cells using a modified Bligh-Dyer method [60]. Briefly, cells were centrifuged at $4600 \mathrm{~g}$ for $15 \mathrm{~min}$ at room temperature, and washed twice with $0.9 \% \mathrm{NaCl}$. Cell pellets were resuspended in $1 \mathrm{~mL}$ of $0.9 \% \mathrm{NaCl}$ to an $\mathrm{OD}_{600}$ of 50 , followed by addition of $2 \mathrm{~mL}$ chloroform and $1 \mathrm{~mL}$ methanol. Next, cells were briefly vortexed and then sonicated on ice using a Q700 sonicator (Qsonica, LLC) with a $10 \mathrm{~mm}$ sonicator probe tip at $20 \%$ amplitude using a program of $1 \mathrm{~s}$ on and $1 \mathrm{~s}$ off for $2.5 \mathrm{~min}$. Following sonication, $1 \mathrm{~mL}$ of chloroform, followed by $1 \mathrm{~mL}$ of $0.9 \% \mathrm{NaCl}$, was added to the mixture to induce phase separation, and the bottom organic phase was removed by glass pipet. The upper aqueous phase was re-extracted twice with $3.8 \mathrm{~mL}$ chloroform, and the organic phases were pooled and dried under a nitrogen stream and stored at $-20{ }^{\circ} \mathrm{C}$ until further use. After extraction, crude lipid extracts were resuspended in 2:1 chloroform:methanol (v/v) for analysis. $50 \mu \mathrm{g}$ of butylated hydroxytoluene (BHT) was added after extraction to prevent oxidation of lipids.

\section{Column fractionation of lipid extracts}

The crude lipid extracts were separated by solid phase extraction using aminopropyl cartridges at room temperature following a previously described method [61] with some modifications. Briefly, a Macherey-Nagel Chromabond $^{\circledR} \quad \mathrm{NH}_{2}$ column $(500 \mathrm{mg})$ was placed under a vacuum manifold for lipid loading and solvent elution with a flow rate of $\sim 0.5 \mathrm{~mL} / \mathrm{min}$ for all solvents. The column was preconditioned with $5 \mathrm{~mL}$ of hexane, and $10 \mathrm{mg}$ of lipids dissolved in $500 \mu \mathrm{L}$ of chloroform:methanol $(2: 1 \mathrm{v} / \mathrm{v})$ was loaded onto the column. Next, seven solvents were used to elute lipids from the column (in the following order): $2 \mathrm{~mL}$ of ethyl acetate:hexane $(15: 85 \mathrm{v} / \mathrm{v}), 3 \mathrm{~mL}$ of chloroform:methanol $(23: 1 \mathrm{v} / \mathrm{v}), 3 \mathrm{~mL}$ of methyl-tert-butyl ether:acetic acid $(98: 5 \mathrm{v} / \mathrm{v}), 3 \mathrm{~mL}$ of acetone:methanol (9:1.35 $\mathrm{v} / \mathrm{v}), 2 \mathrm{~mL}$ of chloroform:methanol $(2: 1 \mathrm{v} / \mathrm{v}), 2 \mathrm{~mL}$ of chloroform:methanol:3.6 $\mathrm{M}$ aqueous ammonium acetate $(30: 60: 8 \mathrm{v} / \mathrm{v})$, and $2 \mathrm{~mL}$ of $0.1 \%(\mathrm{v} / \mathrm{v}) \mathrm{NH}_{4} \mathrm{OH}$ in methanol. The fractionated lipid samples were dried under a stream of nitrogen and stored at $-20{ }^{\circ} \mathrm{C}$ until analysis.

\section{Liquid chromatography/mass spectrometry (LC/MS) analysis}

Lipid extracts were analyzed using an Agilent 1290 Infinity High Performance liquid chromatography system with a 1290 Infinity Autosampler coupled to an Agilent 6460 Triple Quadrupole mass spectrometer with an electrospray ionization source (ESI/MS). Separation of lipids was achieved by a Phenomenex $150 \times 2.1 \mathrm{~mm}$ (2.7 $\mu$ particle size) Kinetex $\mathrm{C}-18$ column at a flow rate of $300 \mu \mathrm{L} / \mathrm{min}$ at room temperature. The mobile phase contained $10 \mathrm{mM}$ ammonium formate ( $\mathrm{pH}$ 5.0) in solvent A-acetonitrile-water (60:40, v/v) and solvent B-2-propanol-acetonitrile (90:10, v/v). A gradient elution in the following manner was applied: $68 \% \mathrm{~A}, 0-1.5 \mathrm{~min}$; 68-55\% A, 1.5-4 min; 55-48\% A, 4-5 min; 48-42\% A, 5-8 min; 42-34\% A, 8-11 min; 34-30\% A, 11-14 min; 30-25\% A, $14-18 \mathrm{~min} ; 25-3 \%$ A, $18-25 \mathrm{~min} ; 3-0 \%$ A, 25-30 min; 0\% A, 30-35 min; 68\% A, 35-40 min. Positive ion mode was used to detect TAG species as $\left[\mathrm{M}+\mathrm{NH}_{4}\right]^{+}$ ions while negative ion mode was used to analyze phospholipids and mycolic acid species as $[\mathrm{M}-\mathrm{H}]^{-}$ions. $40 \mu \mathrm{L}$ of sample in 1:1 chloroform/methanol (v/v) was injected. The ESI/MS spectra for phospholipids (elution time, 4-24 min, 600-900 Da mass range), mycolic acids (22-35 min, 500-800 Da mass range), and TAGs (20-40 min, 600-1000 Da mass range) were signal averaged using Agilent MassHunter software. Principal component analysis was performed using the pca function in MATLAB 2016b. 


\section{Structural characterization by ESI tandem mass spectrometry $\left(\mathrm{MS}^{\mathrm{n}}\right)$}

Both high-resolution $(m / \Delta m=100 \quad 000$ at $m / z \quad 400)$ higher-energy collision activation dissociation and lowenergy collision-induced dissociation tandem mass spectrometry experiments were conducted on a Thermo Scientific (San Jose, CA) LTQ Orbitrap Velos mass spectrometer with Xcalibur operating system. Lipid extracts were dissolved in $0.5 \%(\mathrm{v} / \mathrm{v}) \mathrm{NH}_{4} \mathrm{OH}$ in methanol and were infused $(1.5 \mu \mathrm{L} / \mathrm{min})$ into the ESI source, where the skimmer was set at ground potential, the electrospray needle was set at $4.0 \mathrm{kV}$, and the temperature of the heated capillary was $300{ }^{\circ} \mathrm{C}$. The automatic gain control of the ion trap was set to $5 \times 10^{4}$, with a maximum injection time of $50 \mathrm{~ms}$. Helium was used as the buffer and collision gas at a pressure of $1 \times 10^{-3}$ mbar ( 0.75 mTorr). The $\mathrm{MS}^{\mathrm{n}}$ experiments were carried out with an optimized relative collision energy ranging from 25 to $45 \%$ and with an activation $q$ value at 0.25 , and the activation time at $10 \mathrm{~ms}$ to leave a minimal residual abundance of precursor ion (around 20\%). The mass selection window for the precursor ions was set at $1 \mathrm{Da}$ wide to admit the monoisotopic ion to the ion trap for collision-induced dissociation for unit resolution detection in the ion trap or high-resolution accurate mass detection in the Orbitrap mass analyzer. Mass spectra were accumulated in the profile mode, typically for 2-10 min for $\mathrm{MS}^{\mathrm{n}}$ spectra $(n=2,3,4)$.

\section{Statistical analysis}

To compare lipid profiles between different strains or different conditions, the total ion counts of identified lipid species were normalized to the total ion counts of identified peaks in their respective lipid classes. Statistical significance was determined using a one mean, two-tailed Student's $t$ test with a threshold of significance of $P<0.05$.

\section{Results and discussion}

High-resolution MS ${ }^{n}$ of the WT lipid extract and creation of a lipid species library

Because the lipids of $R$. opacus have not been extensively studied, we performed high-resolution $\left(\mathrm{MS}^{\mathrm{n}}\right)$ analysis on fractionated lipid extracts from the WT strain grown using glucose as a carbon source. A total of 23 phospholipids (11 PIs and 12 PEs), 53 mycolic acids, and 44 TAGs were identified (Tables $1,2,3$ ). The PI species consisted of $\mathrm{C}_{15}-\mathrm{C}_{20}$ acyl chains with $0-2$ double bonds, and PE species contained $\mathrm{C}_{14}-\mathrm{C}_{19}$ acyl chains with 0-2 double bonds (Table 1). These compositions are similar to those observed for other actinomycete strains such as M. smegmatis in which PI and PE are also the most abundant phospholipids [62]. However, we did not observe phosphatidylglycerol (PG) and cardiolipin, which have been observed in other actinomycetes [46, 47]. The mycolic acids contained $\mathrm{C}_{30}-\mathrm{C}_{42}$ meromycolate chains with 0-4 double bonds, and $\mathrm{C}_{12}-\mathrm{C}_{18} \alpha$-branches with $0-1$ double bond (Table 2). These structures are also similar to those found in other Rhodococcus species [50, 63]. TAG species had 0-4 double bonds and a combined $\mathrm{C}_{36}-\mathrm{C}_{57}$ acyl chain carbons from three acyl groups (Table 3). To account for changes between strains and growth conditions, a lipid species library was also generated based on the observed acyl chain lengths and double bond numbers (Additional file 2: Table S1).

\section{LC/MS and principal component analysis of WT and evol40 lipid extracts}

Using LC/MS and our lipid species library, we compared lipid species from the WT and evol40 strains from each growth condition using principal component analysis (PCA) to detect overall changes between samples (Fig. 2; Additional file 2: Table S1): $1 \mathrm{~g} / \mathrm{L}$ glucose (glucose), $0.75 \mathrm{~g} / \mathrm{L}$ phenol (low phenol), or $1.5 \mathrm{~g} / \mathrm{L}$ phenol (high phenol, evol40 only) as a sole carbon source. The WT low phenol, the evol40 low phenol, and the evol40 high phenol data points were generally well-separated from others, while the WT glucose and the evol40 glucose data points clustered together. These results suggest that both strains alter multiple lipid types in low phenol compared to glucose and that the evol40 strain has a lipid profile distinct from that of the WT strain in both phenol growth conditions.

\section{Profiling of mycolic acid species in different growth conditions}

Mycolic acids have been implicated in the high tolerance of mycobacteria to antibiotics, and they have been shown to change in actinomycetes in response to aromatic compounds $[64,65]$. Thus, we hypothesized that WT and evol40 would alter its mycolic acid composition in phenol relative to glucose, and evol40 would have an altered composition compared to the WT strain in phenol. In low phenol relative to glucose, the average mycolic acid double bond number decreased by $12 \%$ in the WT strain and by $16 \%$ in evol40 $(P=0.044$ and $P=0.003$, respectively; one mean, two-tailed Student's $t$ test; Fig. 3a, Additional file 1: Fig. S1, and Additional file 2). However, the average mycolic acid double bond number was not significantly different between the two strains in low phenol $(P=0.746)$. For evol40, this average decreased further by $13 \%$ in high phenol relative to low phenol $(P=0.008)$. These observations are consistent with the findings obtained by GC/MS analysis that fatty acids derived from mycolic acids in $R$. opacus PWD4 had decreased double bond numbers during growth in the presence of chlorophenol (not as a sole carbon source) compared 
Table 1 Phospholipid species identified in R. opacus PD630

\begin{tabular}{|c|c|c|c|c|c|c|}
\hline \multirow{2}{*}{$\begin{array}{l}\text { Measured } m / z(\mathrm{Da}) \\
{[\mathrm{M}-\mathrm{H}]^{-}}\end{array}$} & \multirow[t]{2}{*}{ Rel. intensity (\%) } & \multirow{2}{*}{$\begin{array}{l}\text { Theoretical } \\
\text { mass (Da) }\end{array}$} & \multirow[t]{2}{*}{ Deviation (mDa) } & \multirow[t]{2}{*}{ Composition } & \multicolumn{2}{|c|}{ Structures } \\
\hline & & & & & Major & Minor isomer \\
\hline \multicolumn{7}{|c|}{ Phosphatidylinositol (PI) species } \\
\hline 819.5026 & 2.1 & 819.5029 & -0.31 & $\mathrm{C} 42 \mathrm{H} 76 \mathrm{O} 13 \mathrm{P}$ & $17: 1 / 16: 1$ & \\
\hline 821.5181 & 30.99 & 821.5186 & -0.41 & $\mathrm{C} 42 \mathrm{H} 78 \mathrm{O} 13 \mathrm{P}$ & 17:1/16:0 & 18:1/15:0 \\
\hline 823.5336 & 14.78 & 823.5342 & -0.58 & $\mathrm{C} 42 \mathrm{H} 80 \mathrm{O} 13 \mathrm{P}$ & 17:0/16:0 & \\
\hline 833.5182 & 3.62 & 833.5186 & -0.31 & $\mathrm{C} 43 \mathrm{H} 78 \mathrm{O} 13 \mathrm{P}$ & $18: 1 / 16: 1$ & \\
\hline 835.5338 & 65.67 & 835.5342 & -0.39 & $\mathrm{C} 43 \mathrm{H} 80 \mathrm{O} 13 \mathrm{P}$ & 18:1/16:0 & \\
\hline 837.5491 & 44.79 & 837.5499 & -0.73 & $\mathrm{C} 43 \mathrm{H} 82 \mathrm{O} 13 \mathrm{P}$ & 18:0/16:0 & \\
\hline 847.5337 & 2.3 & 847.5342 & -0.51 & C44 H80 O13 P & 19:1/16:1 & 18:1/17:1 \\
\hline 849.5493 & 35.85 & 849.5499 & -0.5 & $\mathrm{C} 44 \mathrm{H} 82 \mathrm{O} 13 \mathrm{P}$ & 19:1/16:0 & \\
\hline 851.5648 & 100 & 851.5655 & -0.72 & $\mathrm{C} 44 \mathrm{H} 84 \mathrm{O} 13 \mathrm{P}$ & 19:0/16:0 & \\
\hline 863.565 & 2.17 & 863.5655 & -0.51 & $\mathrm{C} 45 \mathrm{H} 84 \mathrm{O} 13 \mathrm{P}$ & 19:0/17:1 & 20:1/16:0 \\
\hline 865.5806 & 3.8 & 865.5812 & -0.56 & $\mathrm{C} 45 \mathrm{H} 86 \mathrm{O} 13 \mathrm{P}$ & 19:0/17:0 & \\
\hline \multicolumn{7}{|c|}{ Phosphatidylethanolamine (PE) species } \\
\hline 674.4764 & 4.09 & 674.4766 & -0.18 & C36 H69 O8 N P & 17:1/14:0 & 16:1/15:0 \\
\hline 686.4762 & 5.57 & 686.4766 & -0.38 & C37 H69 O8 N P & 16:1/16:0 & \\
\hline 688.492 & 26.9 & 688.4923 & -0.24 & $\mathrm{C} 37 \mathrm{H} 71 \mathrm{O} 8 \mathrm{~N} P$ & 18:1/14:0 & $17: 1 / 15: 0,16: 1 / 16: 0$ \\
\hline 700.4921 & 27.92 & 700.4923 & -0.19 & $\mathrm{C} 38 \mathrm{H} 71 \mathrm{O} 8 \mathrm{NP}$ & $17: 1 / 16: 1$ & \\
\hline 702.5077 & 57.4 & 702.5079 & -0.21 & $\mathrm{C} 38 \mathrm{H} 73 \mathrm{O} 8 \mathrm{NP}$ & 17:1/16:0 & 18:1/15:0 \\
\hline 704.5229 & 1.33 & 704.5236 & -0.71 & $\mathrm{C} 38 \mathrm{H} 75 \mathrm{O} 8 \mathrm{~N} P$ & 17:0/16:0 & 18:0/15:0, 19:0/14:0 \\
\hline 714.5077 & 75.12 & 714.5079 & -0.2 & C39 H73 O8 N P & 18:1/16:1 & \\
\hline 716.5233 & 100 & 716.5236 & -0.28 & C39 H75 O8 N P & 18:1/16:0 & \\
\hline 718.5385 & 3.66 & 718.5392 & -0.76 & C39 H77 O8 N P & 18:0/16:0 & \\
\hline 728.5233 & 5.25 & 728.5236 & -0.25 & $\mathrm{C} 40 \mathrm{H} 75 \mathrm{O} 8 \mathrm{~N} P$ & 19:1/16:1 & 18:1/17:1 \\
\hline 730.539 & 29.91 & 730.5392 & -0.25 & $\mathrm{C} 40 \mathrm{H} 77 \mathrm{O} 8 \mathrm{~N} P$ & 19:0/16:1 & \\
\hline 732.5546 & 8.08 & 732.5549 & -0.24 & $\mathrm{C} 40 \mathrm{H} 79 \mathrm{O} 8 \mathrm{~N} P$ & 19:0/16:0 & \\
\hline
\end{tabular}

to the absence of chlorophenol [52]. Thus, our observations may indicate that increased mycolic acid saturation is a general response of $R$. opacus species to aromatic compounds.

Carbon numbers of mycolic acids were shifted in phenol relative to glucose (Fig. $3 \mathrm{~b}$ ). In the WT strain, the average carbon number of mycolic acids was similar in both glucose and low phenol $(P=0.79)$, while the average carbon number of mycolic acids decreased by $\sim 2$ carbons $(P=0.001)$ for evol40 in low phenol relative to glucose (Fig. 3b, Additional file 1: Figs. S2, S3). The average mycolic acid carbon number was also significantly different between the two strains in low phenol $(P=0.027)$, suggesting that the two strains remodel their mycomembranes differently in response to phenol. In addition, evol40 decreased its average mycolic acid carbon number by another $\sim 1$ carbon in high phenol relative to low phenol $(P=0.023$; Additional file 1: Figs. S2, S3). Decreased mycolic acid chains lengths were also observed for $R$. opacus PWD4 in the presence of chlorophenol [52]. Overall, shorter mycolic acid chain lengths in evol40 during growth using phenol suggest that potential alterations in mycomembrane composition could affect phenol tolerance.

\section{Profiling of phospholipid species in different growth conditions}

The inner membrane consists of phospholipids in $R$. opacus (Fig. 1), and some bacteria modify phospholipid head groups and the number and type of double bonds in response to organic solvents and aromatic compounds $[40,66,67]$. We compared the ratio of the two dominant phospholipid species in $R$. opacus, PI and PE, for each strain and growth condition, hypothesizing that $R$. opacus might also change phospholipid composition during growth using phenol as a sole carbon source (Fig. 4a). The $\mathrm{PI} / \mathrm{PE}$ ratio increased by $130 \%$ for the WT strain and $60 \%$ for the evol40 strain in the low phenol condition compared to the glucose condition $(P=0.042$ and $P=0.026$, respectively; one mean, two-tailed Student's $t$ test). However, there was not a significant difference in the PI/PE ratio between the WT and the evol40 strain in the low phenol condition $(P=0.313)$. In the evol40 strain, the PI/ $\mathrm{PE}$ ratio was $240 \%$ higher in high phenol relative to low 
Table 2 Mycolic acid species identified in R. opacus PD630

\begin{tabular}{|c|c|c|c|c|c|c|}
\hline \multirow{2}{*}{$\begin{array}{l}\text { Measured } m / z(D a) \\
{[M-H]^{-}}\end{array}$} & \multirow{2}{*}{$\begin{array}{l}\text { Theoretical } \\
\text { mass }(\mathrm{Da})\end{array}$} & \multirow[t]{2}{*}{ Deviation (mDa) } & \multirow[t]{2}{*}{ Composition } & \multirow[t]{2}{*}{ Rel. intensity (\%) } & \multicolumn{2}{|c|}{ Structure (meromycolate chain/a-branch) } \\
\hline & & & & & Major structures & Other isomers \\
\hline 677.6450 & 677.6453 & -0.29 & $\mathrm{C} 44 \mathrm{H} 85 \mathrm{O} 4$ & 0.6 & & \\
\hline 679.6606 & 679.6610 & -0.39 & $\mathrm{C} 44 \mathrm{H} 87 \mathrm{O} 4$ & 0.82 & & \\
\hline 687.6656 & 687.6661 & -0.43 & $\mathrm{C} 46 \mathrm{H} 87 \mathrm{O} 3$ & 1.34 & $32: 2 / 14: 0 ; 34: 2 / 12: 0$ & $30: 2 / 16: 0$ \\
\hline 691.6606 & 691.6610 & -0.4 & $\mathrm{C} 45 \mathrm{H} 87 \mathrm{O} 4$ & 0.7 & & \\
\hline 693.6762 & 693.6766 & -0.41 & $\mathrm{C} 45 \mathrm{H} 89 \mathrm{O} 4$ & 1.05 & & \\
\hline 701.6813 & 701.6817 & -0.41 & $\mathrm{C} 47 \mathrm{H} 89 \mathrm{O} 3$ & 2.22 & $31: 2 / 16: 0 ; 33: 2 / 14: 0$ & $32: 2 / 15: 0$ \\
\hline 707.6917 & 707.6923 & -0.62 & $\mathrm{C} 46 \mathrm{H} 91 \mathrm{O} 4$ & 0.72 & & \\
\hline 713.6814 & 713.6817 & -0.31 & $\mathrm{C} 48 \mathrm{H} 89 \mathrm{O} 3$ & 1.98 & $33: 2 / 15: 1 ; 34: 3 / 14: 0$ & \\
\hline 715.6970 & 715.6974 & -0.38 & $\mathrm{C} 48 \mathrm{H} 91 \mathrm{O} 3$ & 9.59 & $32: 2 / 16: 0 ; 34: 2 / 14: 0$ & 33:0/15:0; 35:0/13:0 \\
\hline 717.7124 & 717.7130 & -0.62 & $\mathrm{C} 48 \mathrm{H} 93 \mathrm{O} 3$ & 0.96 & & \\
\hline 719.6919 & 719.6923 & -0.36 & $\mathrm{C} 47 \mathrm{H} 91 \mathrm{O} 4$ & 0.49 & & \\
\hline 721.7074 & 721.7079 & -0.58 & $\mathrm{C} 47 \mathrm{H} 93 \mathrm{O} 4$ & 1.02 & & \\
\hline 727.6969 & 727.6974 & -0.44 & $\mathrm{C} 49 \mathrm{H} 91 \mathrm{O} 3$ & 3.21 & $\begin{array}{c}36: 3 / 13: 0 ; 35: 3 / 14: 0 \\
33: 2 / 16: 1 ; 34: 3 / 15: 0\end{array}$ & $\begin{array}{c}34: 2 / 15: 1 ; 33: 3 / 16: 0 \\
35: 2 / 14: 1 ; 32: 2 / 17: 1\end{array}$ \\
\hline 729.7127 & 729.7130 & -0.33 & $\mathrm{C} 49 \mathrm{H} 93 \mathrm{O} 3$ & 10.71 & $\begin{array}{l}36: 2 / 13: 0 ; 35: 2 / 14: 0 \\
33: 2 / 16: 0\end{array}$ & $32: 2 / 17: 0$ \\
\hline 735.7232 & 735.7236 & -0.42 & $\mathrm{C} 48 \mathrm{H} 95 \mathrm{O} 4$ & 0.51 & & \\
\hline 739.6970 & 739.6974 & -0.35 & $\mathrm{C} 50 \mathrm{H} 91 \mathrm{O} 3$ & 0.44 & $34: 3 / 16: 1$ & $36: 3 / 14: 1$ \\
\hline 741.7127 & 741.7130 & -0.35 & $\mathrm{C} 50 \mathrm{H} 93 \mathrm{O} 3$ & 15.04 & $36: 3 / 14: 0$ & $34: 2 / 16: 1 ; 34: 3 / 16: 0$ \\
\hline 743.7283 & 743.7287 & -0.42 & $\mathrm{C} 50 \mathrm{H} 95 \mathrm{O} 3$ & 29.84 & $34: 2 / 16: 0$ & $36: 2 / 14: 0 ; 35: 2 / 15: 0$ \\
\hline 749.7386 & 749.7392 & -0.62 & $\mathrm{C} 49 \mathrm{H} 97 \mathrm{O} 4$ & 0.69 & & \\
\hline 753.7126 & 753.7130 & -0.42 & $\mathrm{C} 51 \mathrm{H} 93 \mathrm{O} 3$ & 0.86 & & \\
\hline 755.7282 & 755.7287 & -0.45 & $\mathrm{C} 51 \mathrm{H} 95 \mathrm{O} 3$ & 19.96 & $36: 3 / 15: 0 ; 37: 3 / 14: 0$ & $\begin{array}{c}35: 3 / 16: 0 ; 35: 2 / 16: 1 \\
34: 2 / 17: 1 ; 38: 3 / 13: 0\end{array}$ \\
\hline 757.7438 & 757.7443 & -0.5 & $\mathrm{C} 51 \mathrm{H} 97 \mathrm{O} 3$ & 24.26 & $36: 2 / 15: 0 ; 37: 2 / 14: 0$ & $34: 2 / 17: 0 ; 38: 2 / 13: 0$ \\
\hline 763.7543 & 763.7549 & -0.56 & $\mathrm{C} 50 \mathrm{H} 99 \mathrm{O} 4$ & 0.54 & & \\
\hline 767.7283 & 767.7287 & -0.41 & $\mathrm{C} 52 \mathrm{H} 95 \mathrm{O} 3$ & 4.3 & $36: 3 / 16: 1$ & $38: 3 / 14: 1$ \\
\hline 769.7438 & 769.7443 & -0.48 & $\mathrm{C} 52 \mathrm{H} 97 \mathrm{O} 3$ & 60.84 & $36: 3 / 16: 0 ; 38: 3 / 14: 0$ & $37: 3 / 15: 0 ; 36: 2 / 16: 1$ \\
\hline 771.7228 & 771.7236 & -0.76 & $\mathrm{C} 51 \mathrm{H} 95 \mathrm{O} 4$ & 0.52 & & \\
\hline 771.7593 & 771.7600 & -0.7 & $\mathrm{C} 52 \mathrm{H} 99 \mathrm{O} 3$ & 44.81 & $36: 2 / 16: 0$ & $38: 2 / 14: 0 ; 37: 2 / 15: 0$ \\
\hline 773.7388 & 773.7392 & -0.39 & $\mathrm{C} 51 \mathrm{H} 97 \mathrm{O} 4$ & 0.53 & & \\
\hline 777.7700 & 777.7705 & -0.55 & $\mathrm{C} 51 \mathrm{H} 101 \mathrm{O} 4$ & 0.48 & & \\
\hline 781.7439 & 781.7443 & -0.44 & $\mathrm{C} 53 \mathrm{H} 97 \mathrm{O} 3$ & 4.32 & $37: 3 / 16: 1$ & $38: 3 / 15: 1 ; 36: 3 / 17: 1$ \\
\hline 783.7231 & 783.7236 & -0.44 & $\mathrm{C} 52 \mathrm{H} 95 \mathrm{O} 4$ & 0.6 & & \\
\hline 783.7594 & 783.7600 & -0.53 & $\mathrm{C} 53 \mathrm{H} 99 \mathrm{O} 3$ & 52.26 & $37: 3 / 16: 0 ; 38: 3 / 15: 0$ & $39: 3 / 14: 0 ; 36: 3 / 17: 0$ \\
\hline 785.7389 & 785.7392 & -0.37 & $\mathrm{C} 52 \mathrm{H} 97 \mathrm{O} 4$ & 1.28 & h36:3/16:1 & \\
\hline 785.7747 & 785.7756 & -0.88 & $\mathrm{C} 53 \mathrm{H} 101 \mathrm{O} 3$ & 18.21 & $37: 2 / 16: 0$ & $37: 2 / 17: 0 ; 38: 2 / 15: 0$ \\
\hline 787.7544 & 787.7549 & -0.47 & $\mathrm{C} 52 \mathrm{H} 99 \mathrm{O} 4$ & 0.64 & h36:3/16:0 & \\
\hline 795.7595 & 795.7600 & -0.43 & $\mathrm{C} 54 \mathrm{H} 99 \mathrm{O} 3$ & 12.65 & $38: 3 / 16: 1$ & \\
\hline 797.7392 & 797.7392 & -0.02 & $\mathrm{C} 53 \mathrm{H} 97 \mathrm{O} 4$ & 0.78 & & \\
\hline 797.7749 & 797.7756 & -0.7 & $\mathrm{C} 54 \mathrm{H} 101 \mathrm{O} 3$ & 100 & $38: 3 / 16: 0$ & $39: 3 / 15: 0 ; 40: 3 / 14: 0$ \\
\hline 799.7542 & 799.7549 & -0.67 & $\mathrm{C} 53 \mathrm{H} 99 \mathrm{O} 4$ & 1.51 & h37:3/16:0 & h36:3/17:0; h38:3/15:0 \\
\hline 801.7697 & 801.7705 & -0.88 & $\mathrm{C} 53 \mathrm{H} 101 \mathrm{O} 4$ & 0.5 & & \\
\hline 809.7751 & 809.7756 & -0.54 & $\mathrm{C} 55 \mathrm{H} 101 \mathrm{O} 3$ & 5.99 & $38: 3 / 17: 1 ; 39: 3 / 16: 1$ & \\
\hline 811.7543 & 811.7549 & -0.6 & $\mathrm{C} 54 \mathrm{H} 99 \mathrm{O} 4$ & 1.77 & & \\
\hline 811.7906 & 811.7913 & -0.63 & $\mathrm{C} 55 \mathrm{H} 103 \mathrm{O} 3$ & 37.52 & $39: 3 / 16: 0$ & $38: 3 / 17: 0 ; 40: 3 / 15: 0$ \\
\hline 813.7698 & 813.7705 & -0.69 & $\mathrm{C} 54 \mathrm{H} 101 \mathrm{O} 4$ & 2.09 & h38:3/16:0 & \\
\hline 823.7907 & 823.7913 & -0.6 & $\mathrm{C} 56 \mathrm{H} 103 \mathrm{O} 3$ & 5.21 & $40: 4 / 16: 0 ; 40: 3 / 16: 1$ & $39: 3 / 17: 1 ; 38: 3 / 18: 1$ \\
\hline 825.7699 & 825.7705 & -0.63 & $\mathrm{C} 55 \mathrm{H} 101 \mathrm{O} 4$ & 1.03 & & \\
\hline
\end{tabular}


Table 2 (continued)

\begin{tabular}{|c|c|c|c|c|c|c|}
\hline \multirow{2}{*}{$\begin{array}{l}\text { Measured } m / z(\mathrm{Da}) \\
{[\mathrm{M}-\mathrm{H}]^{-}}\end{array}$} & \multirow{2}{*}{$\begin{array}{l}\text { Theoretical } \\
\text { mass }(\mathrm{Da})\end{array}$} & \multirow[t]{2}{*}{ Deviation (mDa) } & \multirow[t]{2}{*}{ Composition } & \multirow[t]{2}{*}{ Rel. intensity (\%) } & \multicolumn{2}{|c|}{ Structure (meromycolate chain/a-branch) } \\
\hline & & & & & Major structures & Other isomers \\
\hline 825.8063 & 825.8069 & -0.6 & $\mathrm{C} 56 \mathrm{H} 105 \mathrm{O} 3$ & 27.68 & $40: 3 / 16: 0$ & $39: 3 / 17: 0$ \\
\hline 827.7857 & 827.7862 & -0.49 & $\mathrm{C} 55 \mathrm{H} 103 \mathrm{O} 4$ & 0.96 & & \\
\hline 837.8064 & 837.8069 & -0.54 & $\mathrm{C} 57 \mathrm{H} 105 \mathrm{O} 3$ & 1.42 & $40: 3 / 17: 1 ; 41: 3 / 16: 1$ & \\
\hline 839.7855 & 839.7862 & -0.71 & $\mathrm{C} 56 \mathrm{H} 103 \mathrm{O} 4$ & 1 & & \\
\hline 839.8219 & 839.8226 & -0.7 & $\mathrm{C} 57 \mathrm{H} 107 \mathrm{O} 3$ & 3.51 & $40: 3 / 17: 0 ; 41: 2 / 16: 1$ & \\
\hline 841.8010 & 841.8018 & -0.85 & $\mathrm{C} 56 \mathrm{H} 105 \mathrm{O} 4$ & 0.51 & & \\
\hline 853.8374 & 853.8382 & -0.81 & $\mathrm{C} 58 \mathrm{H} 109 \mathrm{O} 3$ & 0.6 & $42: 3 / 16: 0 ; 41: 3 / 17: 0$ & $40: 3 / 18: 0$ \\
\hline
\end{tabular}

phenol and $440 \%$ higher relative to glucose $(P=0.032$ and $P=0.020$, respectively; one mean, two-tailed Student's $t$ test). PI is an uncommon phospholipid in bacteria and is more commonly found in eukaryotes such as yeast [68]. In actinomycete strains, PI is an essential phospholipid for growth, and it is a precursor for PI-mannoside and other membrane components such as lipoarabinomannan [62, 69]. Modification of phospholipid head groups has been shown to increase tolerance to various compounds in Escherichia coli, including aromatic compounds [70]. This work demonstrates the first study in bacteria where PI is increased in response to phenol and suggests that phospholipid head groups, specifically inositol head groups, could be related to phenol tolerance in R. opacus.

Shifts in the average phospholipid double bond number were also observed (Fig. 4b). Both the WT and evol40 strains had lower percentages of unsaturated phospholipids in low phenol relative to glucose, and the evol40 strain had even lower percentages in high phenol relative to low phenol and glucose (Fig. 4b), a trend that was also observed for mycolic acids (Fig. 3a). This trend toward fewer number of unsaturation (double bonds and cyclic chains) was also generally observed for PI and PE separately (Additional file 1: Fig. S4). While reduction in phospholipid unsaturation may improve tolerance to phenol, it could negatively affect respiratory metabolism and growth by reducing the diffusion of enzymes and electron carriers within the membrane [71].

Although we observed significant changes in chain lengths for mycolic acids in evol40 (Fig. 3b), relatively minor shifts in phospholipid chain lengths occurred, and no clear trend emerged between strains or growth conditions (Fig. 4c, Additional file 1: Figs. S4, S5). Studies in other organisms have shown that the addition of phenol to cultures can also decrease the double bond number of phospholipids [40,66], and studies of derivatized fatty acids from $R$. opacus GM-14, GM-29, and 1CP grown in aromatic compounds also had fewer double bonds compared to those from cells grown using fructose as a sole carbon source [49]. These results suggest that phospholipid unsaturation could be related to phenol tolerance in $R$. opacus species, and modification of phospholipid composition could improve aromatic tolerance and utilization.

\section{Profiling of triacylglycerol species in different growth conditions}

$R$. opacus accumulates large amounts of TAGs under nitrogen limitation using many different carbon sources [25]. To determine if any changes occurred in TAGs, a lipid class important for biofuel production, we analyzed the TAG composition in each strain and growth condition (Fig. 5). We hypothesized that the TAG profile would be different between glucose and low phenol for both strains and between the WT and evo40 strains in phenol. The WT strain decreased the average TAG double bond number by $14 \%$ in low phenol relative to glucose, while the average TAG double bond number remained roughly the same between the two conditions in the evol40 strain $(P=0.005$ and $P=0.93$, respectively; one mean, twotailed Student's $t$ test; Fig. 5a, Additional file 1: Fig. S6). However, evol40 had a $25 \%$ lower average TAG double bond number in high phenol relative to low phenol $\left(P=5 \times 10^{-4}\right)$, which was also significantly lower than the WT in low phenol $(P=0.016)$. This shift to fewer double bonds in the WT strain also occurred in $R$. opacus GM-14, GM-29, and 1CP, in which growth in phenol as a sole carbon source reduced the percentage of double bonds on fatty acid chains compared to fructose as a sole carbon source [49]. The average TAG carbon number slightly increased in low phenol for both strains relative to glucose, but it decreased for evol40 in high phenol relative to low phenol, which makes the trend less clear (Fig. 5b, Additional file 1: Figs. S7, S8). These changes, along with changes in the mycolic acid and phospholipid compositions, suggest that WT and evol40 respond differently to phenol, and lipid unsaturation could play a role in phenol tolerance in $R$. opacus. 
Table 3 Triacylglycerol species identified in R. opacus PD630

\begin{tabular}{|c|c|c|c|c|}
\hline $\begin{array}{l}\text { Measured } m / z(\mathrm{Da}) \\
{\left[\mathrm{M}+\mathrm{NH}_{4}\right]^{+}}\end{array}$ & Rel. intensity (\%) & Theoretical mass ( $\mathrm{Da}$ ) & Deviation (mDa) & Composition \\
\hline 654.5664 & 0.94 & 654.5667 & -0.34 & $\mathrm{C} 39 \mathrm{H} 76 \mathrm{O} 6 \mathrm{~N}$ \\
\hline 668.5819 & 0.49 & 668.5824 & -0.47 & $\mathrm{C} 40 \mathrm{H} 78 \mathrm{O} 6 \mathrm{~N}$ \\
\hline 710.629 & 0.82 & 710.6293 & -0.32 & $\mathrm{C} 43 \mathrm{H} 84 \mathrm{O} 6 \mathrm{~N}$ \\
\hline 724.6447 & 1.45 & 724.645 & -0.27 & $\mathrm{C} 44 \mathrm{H} 86 \mathrm{O} 6 \mathrm{~N}$ \\
\hline 738.6603 & 2.35 & 738.6606 & -0.36 & $\mathrm{C} 45 \mathrm{H} 88 \mathrm{O} 6 \mathrm{~N}$ \\
\hline 750.6605 & 0.75 & 750.6606 & -0.15 & $\mathrm{C} 46 \mathrm{H} 88 \mathrm{O} 6 \mathrm{~N}$ \\
\hline 752.6758 & 2.48 & 752.6763 & -0.45 & $\mathrm{C} 46 \mathrm{H} 90 \mathrm{O} 6 \mathrm{~N}$ \\
\hline 764.676 & 1.42 & 764.6763 & -0.28 & $\mathrm{C} 47 \mathrm{H} 90 \mathrm{O} 6 \mathrm{~N}$ \\
\hline 766.6915 & 4.18 & 766.6919 & -0.44 & C47 H92 O6 N \\
\hline 768.707 & 0.37 & 768.7076 & -0.52 & C47 H94 O6 N \\
\hline 776.6772 & 0.48 & 776.6763 & 0.95 & $\mathrm{C} 48 \mathrm{H} 90 \mathrm{O} 6 \mathrm{~N}$ \\
\hline 778.6919 & 2.17 & 778.6919 & -0.03 & $\mathrm{C} 48 \mathrm{H} 92 \mathrm{O} 6 \mathrm{~N}$ \\
\hline 780.7072 & 5.64 & 780.7076 & -0.41 & C48 H94 O6 N \\
\hline 792.7074 & 5.75 & 792.7076 & -0.18 & C49 H94 O6 N \\
\hline 794.7229 & 14.41 & 794.7232 & -0.36 & $\mathrm{C} 49 \mathrm{H} 96 \mathrm{O} 6 \mathrm{~N}$ \\
\hline 806.7233 & 11.93 & 806.7232 & 0.06 & $\mathrm{C} 50 \mathrm{H} 96 \mathrm{O} 6 \mathrm{~N}$ \\
\hline 808.7385 & 25.6 & 808.7389 & -0.37 & $\mathrm{C} 50 \mathrm{H} 98 \mathrm{O} 6 \mathrm{~N}$ \\
\hline 820.7388 & 35.39 & 820.7389 & -0.08 & $\mathrm{C} 51 \mathrm{H} 98 \mathrm{O} 6 \mathrm{~N}$ \\
\hline 822.7541 & 63.2 & 822.7545 & -0.39 & $\mathrm{C} 51 \mathrm{H} 100 \mathrm{O} 6 \mathrm{~N}$ \\
\hline 834.7544 & 54.02 & 834.7545 & -0.11 & $\mathrm{C} 52 \mathrm{H} 100 \mathrm{O} 6 \mathrm{~N}$ \\
\hline 836.7696 & 79.35 & 836.7702 & -0.55 & $\mathrm{C} 52 \mathrm{H} 102 \mathrm{O} 6 \mathrm{~N}$ \\
\hline 848.7697 & 76.36 & 848.7702 & -0.42 & $\mathrm{C} 53 \mathrm{H} 102 \mathrm{O} 6 \mathrm{~N}$ \\
\hline 850.7851 & 100 & 850.7858 & -0.69 & $\mathrm{C} 53 \mathrm{H} 104 \mathrm{O} 6 \mathrm{~N}$ \\
\hline 858.7538 & 0.38 & 858.7545 & -0.74 & C54 H100 O6 N \\
\hline 860.7711 & 4.48 & 860.7702 & 0.96 & $\mathrm{C} 54 \mathrm{H} 102 \mathrm{O} 6 \mathrm{~N}$ \\
\hline 862.7852 & 49.71 & 862.7858 & -0.59 & C54 H104 O6 N \\
\hline 864.8006 & 55.85 & 864.8015 & -0.83 & $\mathrm{C} 54 \mathrm{H} 106 \mathrm{O} 6 \mathrm{~N}$ \\
\hline 874.7853 & 4.12 & 874.7858 & -0.54 & $\mathrm{C} 55 \mathrm{H} 104 \mathrm{O} 6 \mathrm{~N}$ \\
\hline 876.8008 & 39.32 & 876.8015 & -0.69 & $\mathrm{C} 55 \mathrm{H} 106 \mathrm{O} 6 \mathrm{~N}$ \\
\hline 878.8162 & 40.34 & 878.8171 & -0.96 & $\mathrm{C} 55 \mathrm{H} 108 \mathrm{O} 6 \mathrm{~N}$ \\
\hline 888.8008 & 2.47 & 888.8015 & -0.71 & $\mathrm{C} 56 \mathrm{H} 106 \mathrm{O} 6 \mathrm{~N}$ \\
\hline 890.8164 & 17.49 & 890.8171 & -0.71 & $\mathrm{C} 56 \mathrm{H} 108 \mathrm{O} 6 \mathrm{~N}$ \\
\hline 892.8319 & 19.93 & 892.8328 & -0.91 & $\mathrm{C} 56 \mathrm{H} 110 \mathrm{O} 6 \mathrm{~N}$ \\
\hline 902.8162 & 2.36 & 902.8171 & -0.87 & $\mathrm{C} 57 \mathrm{H} 108 \mathrm{O} 6 \mathrm{~N}$ \\
\hline 904.832 & 17.21 & 904.8328 & -0.73 & $\mathrm{C} 57 \mathrm{H} 110 \mathrm{O} 6 \mathrm{~N}$ \\
\hline 906.8475 & 18.74 & 906.8484 & -0.96 & $\mathrm{C} 57 \mathrm{H} 112 \mathrm{O} 6 \mathrm{~N}$ \\
\hline 916.8319 & 3.39 & 916.8328 & -0.82 & $\mathrm{C} 58 \mathrm{H} 110 \mathrm{O} 6 \mathrm{~N}$ \\
\hline 918.8476 & 11.2 & 918.8484 & -0.84 & $\mathrm{C} 58 \mathrm{H} 112 \mathrm{O} 6 \mathrm{~N}$ \\
\hline 920.8632 & 9.19 & 920.8641 & -0.91 & $\mathrm{C} 58 \mathrm{H} 114 \mathrm{O} 6 \mathrm{~N}$ \\
\hline 930.8476 & 3.06 & 930.8484 & -0.81 & $\mathrm{C} 59 \mathrm{H} 112 \mathrm{O} 6 \mathrm{~N}$ \\
\hline 932.8633 & 9.53 & 932.8641 & -0.81 & $\mathrm{C} 59 \mathrm{H} 114 \mathrm{O} 6 \mathrm{~N}$ \\
\hline 934.8788 & 5.38 & 934.8797 & -0.96 & $\mathrm{C} 59 \mathrm{H} 116 \mathrm{O} 6 \mathrm{~N}$ \\
\hline 944.8631 & 1.96 & 944.8641 & -0.96 & $\mathrm{C} 60 \mathrm{H} 114 \mathrm{O} 6 \mathrm{~N}$ \\
\hline 946.8788 & 3.37 & 946.8797 & -0.87 & $\mathrm{C} 60 \mathrm{H} 116 \mathrm{O} 6 \mathrm{~N}$ \\
\hline
\end{tabular}


a

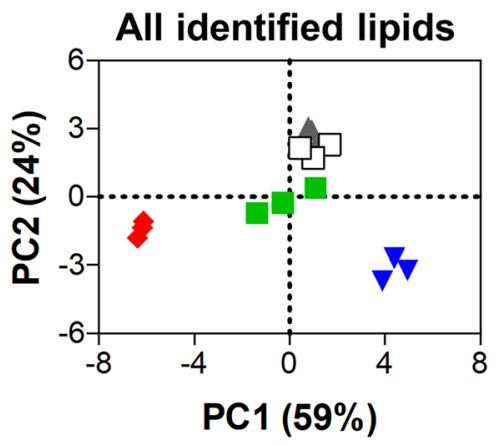

C

Triacylglycerols

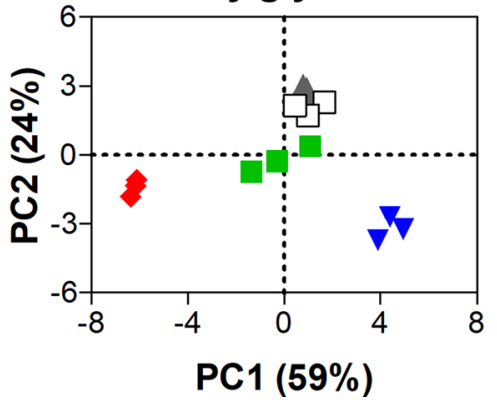

b

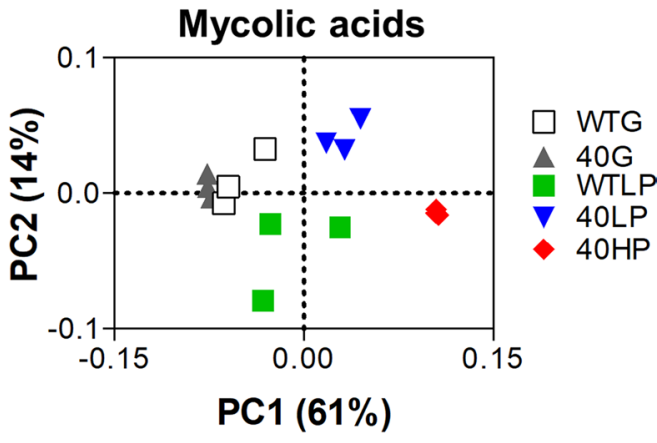

d

Phospholipids

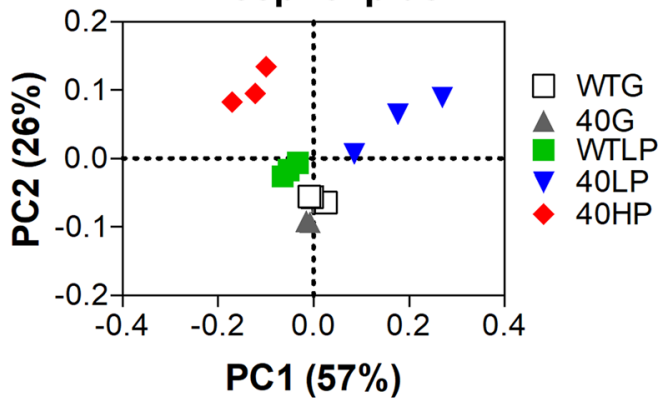

Fig. 2 Principal component analysis of lipid types identified using LC/MS. a Principal component analysis (PCA) of all identified lipids. b PCA of mycolic acid species. c PCA of triacylglycerol species. d PCA of phospholipid species. Because triacylglycerol ion counts are $>98 \%$ of total ion counts in each sample, the PCA plots for all lipid species (a) and triacylglycerol species (c) are almost identical. Each point represents one replicate. WTG WT strain grown in $1 \mathrm{~g} / \mathrm{L}$ glucose, $40 \mathrm{G}$ evol 40 grown in $1 \mathrm{~g} / \mathrm{L}$ glucose, WTLPWT strain grown in $0.75 \mathrm{~g} / \mathrm{L}$ phenol, $40 \mathrm{~L} P$ evol40 strain grown in $0.75 \mathrm{~g} / \mathrm{L}$ phenol, 40HP evol40 strain grown in $1.5 \mathrm{~g} / \mathrm{L}$ phenol, $P C 1$ 1st principal component, $P C 2$ 2nd principal component. Percent represents the amount of variance explained by each principal component.

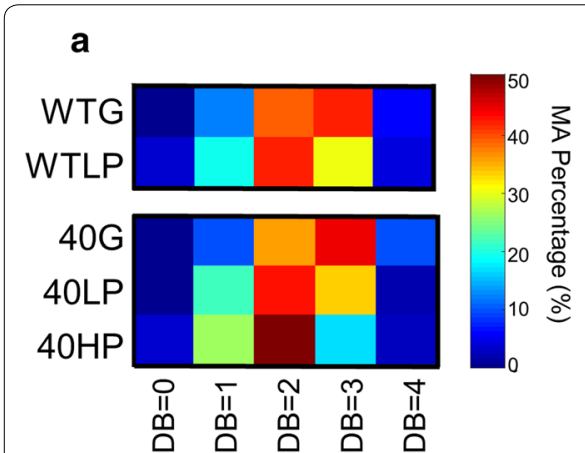

\section{b}

Fig. 3 Mycolic acid composition of R. opacus strains using glucose or phenol as a sole carbon source. a Heat map of double bond (DB) numbers for mycolic acids (MAs) in the WT and evol40 strains. The values shown in the heat map are the average of three replicates. See color bar for scale. The DB number represents the total number of double bonds and cyclopropane units on acyl chains. $\mathbf{b}$ Heat map of MA carbon (C) number distribution, defined as the total number of carbons located on acyl chains. The values shown in the heat map are the average of three replicates. See color bar for scale. WTG WT strain grown in $1 \mathrm{~g} / \mathrm{L}$ glucose (glucose), $40 \mathrm{G}$ evol40 grown in glucose, WTLP WT strain grown in $0.75 \mathrm{~g} / \mathrm{L}$ phenol (low phenol), 40LP evol40 strain grown in low phenol, $40 \mathrm{HP}$ evol40 strain grown in $1.5 \mathrm{~g} / \mathrm{L}$ phenol (high phenol). MA percentage is defined as the total ion counts of each category (DB number or $\mathrm{C}$ number) divided by the total ion counts of all mycolic acids detected in each sample. 

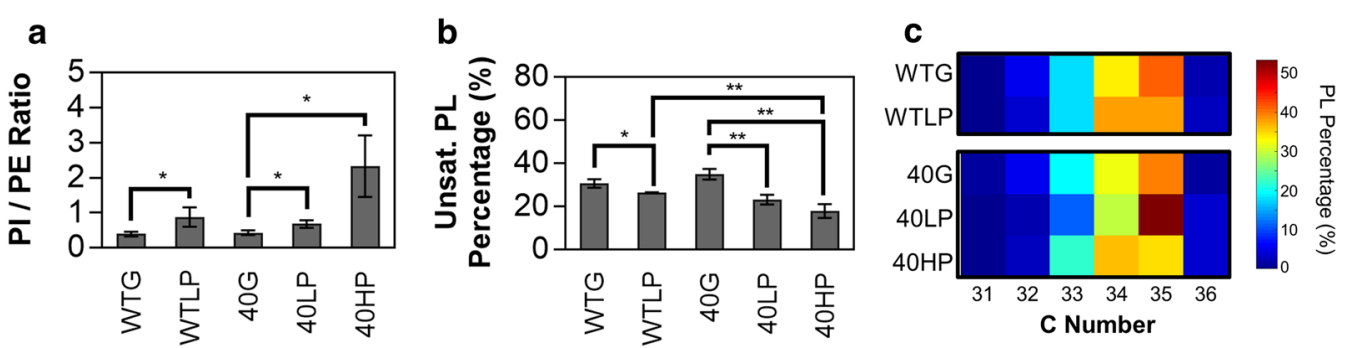

Fig. 4 Phospholipid composition of R. opacus strains using glucose or phenol as a sole carbon source. a Ratio of phosphatidylinositol (PI) to phosphatidylethanolamine (PE) total ion counts in the WT and evol40 strains using glucose or phenol as a sole carbon source. b Percentage of unsaturated phospholipids (PLs) (i.e., phospholipids with at least one unsaturated fatty acyl substituent) in WT and evol40 strains using glucose or phenol as a sole carbon source. c Distribution of phospholipid carbon (C) numbers in WT and evol40 strains. Here, C number is defined as the total number of acyl chain carbons, and unsaturation means double bonds and cyclic chains on acyl substituents. Each square is the average of three replicates. PL percentage is defined as the total ion counts of each category (unsaturated phospholipids or $\mathrm{C}$ number) divided by the total ion counts of all detected PI and PE species in the sample. For A and B, bars represent the average of three replicates, error bars represent one standard deviation, and statistical significance was determined using a one mean, two-tailed Student's $t$ test $\left({ }^{*} P<0.05 ; * * P<0.01\right)$. WTG WT strain grown in $1 \mathrm{~g} / \mathrm{L}$ glucose (glucose), $40 \mathrm{G}$ evol40 grown in glucose, WTLPWT strain grown in $0.75 \mathrm{~g} / \mathrm{L}$ phenol (low phenol), $40 \mathrm{LP}$ evol40 strain grown in low phenol, $40 \mathrm{HP}$ evol40 strain grown in $1.5 \mathrm{~g} / \mathrm{L}$ phenol (high phenol).

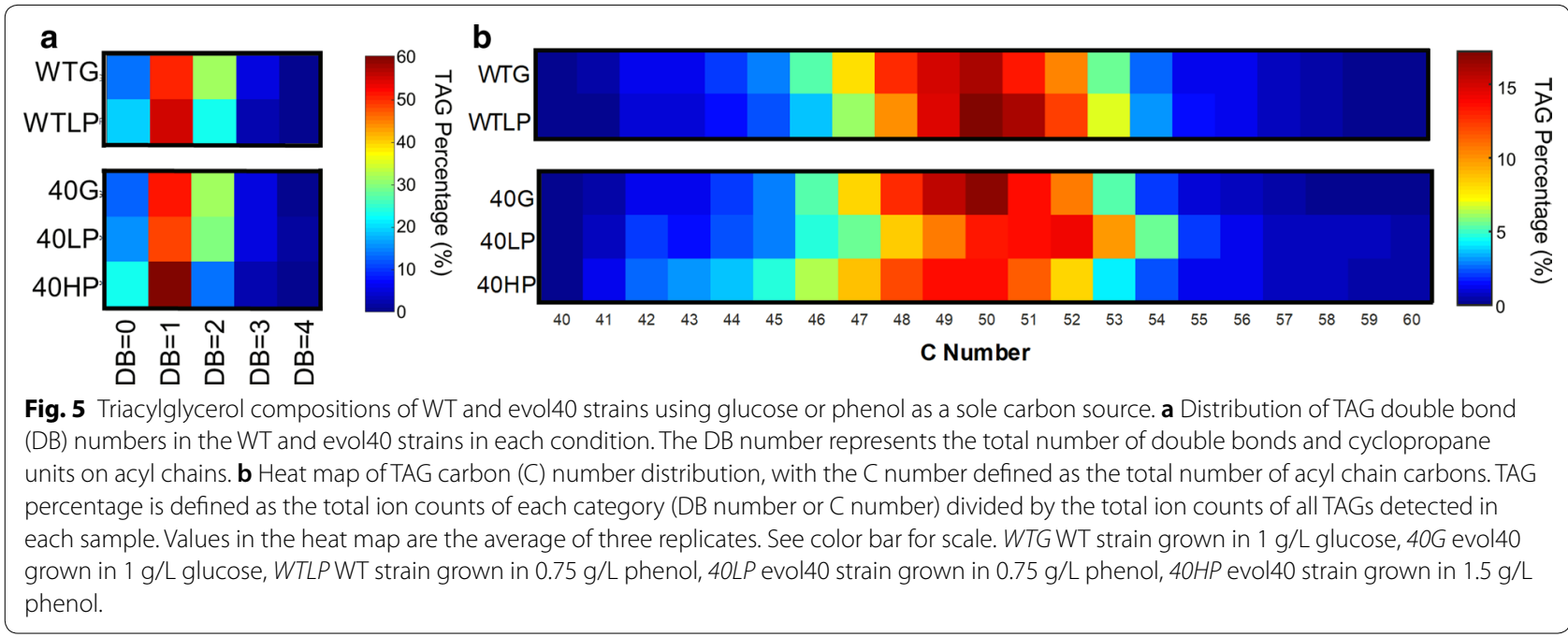

\section{Conclusions}

Hybrid chemical and biological approaches to lignin valorization require a deeper understanding of bacterial aromatic tolerance and utilization mechanisms. $R$. opacus is a promising host for the biological conversion of lignin-derived aromatic compounds into valuable products, but the role of its lipid metabolism in aromatic tolerance is not well understood. This study characterized the three lipid types (mycolic acids, phospholipids, and TAGs) in the WT and a phenol-adapted strain of $R$. opacus (evol40) when grown using glucose or phenol as a sole carbon source. For all lipid species characterized, a general trend toward fewer double bonds in lipid species was observed during growth using phenol. Mycolic acids had fewer double bonds during growth using phenol compared to glucose for both strains, and mycolic acid chain lengths in evol40, but not in the WT strain, were significantly shorter in phenol conditions compared to the glucose condition, showing the similarity and difference in phenol responses between the two strains. The relative amount of PI increased in phenol growth conditions, which suggests that phospholipid head groups, specifically inositol head groups, could play a role in $R$. opacus phenol tolerance. Overall, this work represents the first lipidomic study of membrane and TAG lipids in $R$. opacus using phenol as a sole carbon source. These results suggest that the lipid metabolism of $R$. opacus is related to phenol tolerance by affecting the mycomembrane and phospholipid membrane compositions during growth using phenol. We envision that the aromatic tolerance of $R$. opacus or other strains of interest can be further understood and engineered for improved 
lignin hybrid/bioconversion by changing and controlling expression levels of relevant enzymes, including fatty acid desaturases, cyclopropane fatty acid synthases, and phospholipid biosynthesis enzymes.

\section{Additional files}

Additional file 1: Figure S1. Double bond (DB) numbers of mycolic acid (MA) species. A. Distribution of mycolic acid DB numbers. B. Average mycolic acid DB numbers. The average DB number was calculated using the following equation: Average $\mathrm{DB}$ number $=\sum F_{i} n_{i}$, where $F$ is the fraction of the total mycolic acids with a particular double bond number and $n$ is the corresponding double bond number. WTG $=W T$ strain grown in $1 \mathrm{~g} / \mathrm{L}$ glucose, $40 \mathrm{G}=$ evol 40 grown in $1 \mathrm{~g} / \mathrm{L}$ glucose. WTLP =WT strain grown in $0.75 \mathrm{~g} / \mathrm{L}$ phenol, $40 \mathrm{LP}=$ evol 40 strain grown in $0.75 \mathrm{~g} / \mathrm{L}$ phenol $40 \mathrm{HP}=$ evol 40 strain grown in $1.5 \mathrm{~g} / \mathrm{L}$ phenol. MA percentage is defined as the total ion counts of each category (i.e. DB number) divided by the total ion counts of all detected MA species in the sample. Bars represent the average of three replicates, and error bars represent one standard deviation. For A, statistical significance was calculated using a one mean, two tailed Student's $t$ test with $P<0.05$ as a threshold for statistical significance. Letters above bars indicate statistical significance between strain/growth conditions. For $\mathrm{A}, \mathrm{a}=$ WTLP vs. $40 \mathrm{LP}, \mathrm{b}=$ WTLP vs. $40 \mathrm{HP}$, $\mathrm{C}=40 \mathrm{LP}$ vs. $40 \mathrm{HP}, \mathrm{d}=\mathrm{WTG}$ vs. WTLP, $\mathrm{e}=40 \mathrm{G}$ vs. $40 \mathrm{LP}, \mathrm{f}=40 \mathrm{G}$ vs. $40 \mathrm{HP}$. For $B$, *indicates $P<0.05,{ }^{* *}$ indicates $P<0.01,{ }^{* * *}$ indicates $P<0.001$. Figure $\mathbf{S 2}$. Average mycolic acid (MA) carbon (C) numbers. WTG $=$ WT strain grown in $1 \mathrm{~g} / \mathrm{L}$ glucose, $40 \mathrm{G}=$ evol40 grown in $1 \mathrm{~g} / \mathrm{L}$ glucose. WTLP $=$ WT strain grown in $0.75 \mathrm{~g} / \mathrm{L}$ phenol, $40 \mathrm{LP}=$ evol 40 strain grown in $0.75 \mathrm{~g} / \mathrm{L}$ phenol, $40 \mathrm{HP}=$ evol 40 strain grown in $1.5 \mathrm{~g} / \mathrm{L}$ phenol. The average $C$ number was calculated using the following equation: Average $C$ number $=\sum F_{i} C_{i}$ where $F$ is the fraction of the total mycolic acids with a particular carbon number and $C$ is the corresponding carbon number. Bars represent the average of three replicates, and error bars represent one standard deviation. Statistical significance was calculated using a one mean, two tailed Student's $t$ test with $P<0.05$ as a threshold for statistical significance. ${ }^{*} P<0.05,{ }^{* *} P<0.01,{ }^{* * *} P<0.001$. Figure $\mathbf{S 3}$. Carbon (C) number distribution of mycolic acid species. WTG $=$ WT strain grown in $1 \mathrm{~g} / \mathrm{L}$ glucose, $40 \mathrm{G}=$ evol40 grown in $1 \mathrm{~g} / \mathrm{L}$ glucose. WTLP $=W T$ strain grown in $0.75 \mathrm{~g} / \mathrm{L}$ phenol, $40 \mathrm{LP}=$ evol 40 strain grown in $0.75 \mathrm{~g} / \mathrm{L}$ phenol, $40 \mathrm{HP}=$ evol 40 strain grown in $1.5 \mathrm{~g} / \mathrm{L}$ phenol. Mycolic acid percentage is defined as the total ion counts of each category (i.e. C number) divided by the total ion counts of all detected mycolic acid species in the sample. Bars represent the average of three replicates, and error bars represent one standard deviation. Figure S4. Phosphatidylinositol (PI) and phosphatidylethanolamine (PE) average carbon (C) number and unsaturation percentage. A. Average PI carbon number. B. Average PE carbon number. C. Percentage of unsaturated PI species. D. Percentage of unsaturated PE species. WTG $=W T$ strain grown in $1 \mathrm{~g} / \mathrm{L}$ glucose, $40 \mathrm{G}=$ evol 40 grown in $1 \mathrm{~g} / \mathrm{L}$ glucose. WTLP $=W T$ strain grown in $0.75 \mathrm{~g} / \mathrm{L}$ phenol, $40 \mathrm{LP}=$ evol 40 strain grown in $0.75 \mathrm{~g} / \mathrm{L}$ phenol, $40 \mathrm{HP}=$ evol 40 strain grown in $1.5 \mathrm{~g} / \mathrm{L}$ phenol. The average $C$ number was calculated using the following equation: Average $C$ number $=\sum F_{i} C_{i}$, where $F$ is the fraction of the total $\mathrm{PI}$ or $\mathrm{PE}$ species with a particular carbon number and $C$ is the corresponding carbon number. Unsaturated PI (or PE) percentage is defined as the total ion counts of PI (or PE) species with at least one unsaturated fatty acyl substituent divided by the total ion counts of all detected PI (Or PE) species in the sample. Bars represent the average of three replicates, and error bars represent one standard deviation. Statistical significance was calculated using a one mean, two tailed Student's $t$ test with $P<0.05$ as a threshold for statistical significance. For $C$ and $D,{ }^{*} P<0.05,{ }^{* *} P<0.01,{ }^{* * *} P<0.001$. Figure S5. Carbon (C) number distribution of phospholipid (PL) species. WTG $=$ WT strain grown in $1 \mathrm{~g} / \mathrm{L}$ glucose, $40 \mathrm{G}=$ evol 40 grown in $1 \mathrm{~g} / \mathrm{L}$ glucose. $W T L P=W T$ strain grown in $0.75 \mathrm{~g} / \mathrm{L}$ phenol, $40 \mathrm{LP}=$ evol 40 strain grown in $0.75 \mathrm{~g} / \mathrm{L}$ phenol, $40 \mathrm{HP}=$ evol 40 strain grown in $1.5 \mathrm{~g} / \mathrm{L}$ phenol. PL percentage is defined as the total ion counts of each category (i.e. $C$ number) divided by the total ion counts of all detected PL species in the sample. Bars represent the average of three replicates, and error bars represent one standard deviation. Statistical significance was calculated using a one mean, two tailed Student's $t$ test with $P<0.05$ as a threshold for statistical significance. Letters above bars indicate statistical significance between strain/growth conditions. $a=W T L P$ vs. $40 L P, b=W T L P$ vs. $40 \mathrm{HP}, \mathrm{c}=40 \mathrm{LP}$ vs. $40 \mathrm{HP}, \mathrm{d}=$ WTG vs. WTLP, $\mathrm{e}=40 \mathrm{G}$ vs. $40 \mathrm{LP}, \mathrm{f}=40 \mathrm{G}$ vs. 40HP. Figure S6. Triacylglycerol (TAG) double bond (DB) numbers. A. Distribution of TAG double bond (DB) numbers. B. Average TAG DB numbers. The average DB number for each sample was calculated using the following equation: Average DB number $=\sum F_{i} n_{i}$, where $F$ is the fraction of the total TAGs with a particular double bond number and $n$ is the corresponding double bond number. WTG $=$ WT strain grown in $1 \mathrm{~g} / \mathrm{L}$ glucose, $40 \mathrm{G}=$ evol40 grown in $1 \mathrm{~g} / \mathrm{L}$ glucose. WTLP $=W T$ strain grown in $0.75 \mathrm{~g} / \mathrm{L}$ phenol, $40 \mathrm{LP}=$ evol 40 strain grown in $0.75 \mathrm{~g} / \mathrm{L}$ phenol, $40 \mathrm{HP}=$ evol 40 strain grown in $1.5 \mathrm{~g} / \mathrm{L}$ phenol. TAG percentage is defined as the total ion counts of each category (i.e. DB number) divided by the total ion counts of all detected TAG species in the sample. Bars represent the average of three replicates, and error bars represent one standard deviation. For A, statistical significance was calculated using a one mean, two tailed Student's $t$ test with $P<0.05$ as threshold for statistical significance. Letters above bars indicate statistical significance between strain/growth conditions. For $A, a=$ WTLP vs. 40LP, $b=$ WTLP vs. $40 \mathrm{HP}, \mathrm{c}=40 \mathrm{LP}$ vs. $40 \mathrm{HP}, \mathrm{d}=$ WTG vs. WTLP, $\mathrm{e}=40 \mathrm{G}$ vs. $40 \mathrm{LP}, \mathrm{f}=40 \mathrm{G}$ vs. $40 \mathrm{HP}$. For $B,{ }^{*} P<0.05,{ }^{* *} P<0.01,{ }^{* * *} P<0.001$. Figure S7. Triacylglycerol (TAG) carbon (C) number distribution. WTG $=$ WT strain grown in $1 \mathrm{~g} / \mathrm{L}$ glucose, $40 \mathrm{G}=$ evol40 grown in $1 \mathrm{~g} / \mathrm{L}$ glucose. WTLP $=W T$ strain grown in $0.75 \mathrm{~g} / \mathrm{L}$ phenol, $40 \mathrm{LP}=$ evol 40 strain grown in $0.75 \mathrm{~g} / \mathrm{L}$ phenol, $40 \mathrm{HP}=$ evol 40 strain grown in $1.5 \mathrm{~g} / \mathrm{L}$ phenol. TAG percentage is defined as the total ion counts of each category (i.e. C number) divided by the total ion counts of all detected TAG species in the sample. Bars represent the average of three replicates, and error bars represent one standard deviation. Figure S8. Average triacylglycerol (TAG) carbon (C) number by strain and growth condition. WTG $=$ WT strain grown in $1 \mathrm{~g} / \mathrm{L}$ glucose, $40 \mathrm{G}=$ evol40 grown in $1 \mathrm{~g} / \mathrm{L}$ glucose. WTLP $=$ WT strain grown in $0.75 \mathrm{~g} / \mathrm{L}$ phenol, $40 \mathrm{LP}=$ evol 40 strain grown in $0.75 \mathrm{~g} / \mathrm{L}$ phenol, $40 \mathrm{HP}=$ evol 40 strain grown in $1.5 \mathrm{~g} / \mathrm{L}$ phenol. The average $C$ number for each sample was calculated using the following equation: Average $C$ number $=\sum F_{i} C_{i}$, where $F$ is the fraction of the total TAGs with a particular carbon number and $C$ is the corresponding carbon number. Bars represent the average of three replicates, and error bars represent one standard deviation. Statistical significance was calculated using a one mean, two tailed Student's $t$ test with $P<0.05$ as threshold for statistical significance. ${ }^{*} P<0.05,{ }^{* *} P<0.01,{ }^{* * *} P<0.001$

Additional file 2: Table S1. Excel file containing the lipid library and lipid library matches from LC/MS data. For all tabs, WTG $=$ WT strain grown in $1 \mathrm{~g} / \mathrm{L}$ glucose (glucose), 40G =evol40 grown in glucose, WTLP $=W T$ strain grown in $0.75 \mathrm{~g} / \mathrm{L}$ phenol (low phenol), $40 \mathrm{LP}=$ evol 40 strain grown in low phenol, $40 \mathrm{HP}=$ evol 40 strain grown in $1.5 \mathrm{~g} / \mathrm{L}$ phenol (high phenol), and SD = standard deviation. Lipid species are abbreviated using their carbon number $(C)$ and double bond number (DB), where the carbon number is the number of acyl carbons and the double bond number is the number of double bonds and cyclopropane units on acyl chains. Tab 1. TAG library. Library of triacylglycerol (TAG) species based on $\mathrm{MS}^{n}$ data. Lipid species in the library that were observed in $\mathrm{MS}^{\mathrm{n}}$ analysis (Observed $\mathrm{MS}^{\mathrm{n}}$ column) are indicated $u$ sing " $\mathrm{x}$ " (see Table 3). Tab 2. TAG data. Normalized TAG species ion counts from LC/MS data. Species amounts in each replicate (rep) are normalized by dividing the total ion counts of individual species by the total ion counts of all detected TAG species in the sample. Tab 3. PL library. Library of phospholipid (PL) species based on $\mathrm{MS}^{n}$ data. Lipid species in the library that were observed in $\mathrm{MS}^{\mathrm{n}}$ analysis (Observed $\mathrm{MS}^{\mathrm{n}}$ column) are indicated using " $x$ " (see Table 1). Tab 4. PL data. Normalized PL species ion counts from LC/MS data. Species amounts in each replicate (rep) are normalized by dividing the total ion counts of individual species by the total ion counts of all detected phosphatidylinositol (PI) or phosphatidylethanolamine (PE) species in the sample. Tab 5. MA library. Library of mycolic acid (MA) species based on MS $^{n}$ data. Lipid species in the library that were observed in $\mathrm{MS}^{\mathrm{n}}$ analysis (Observed $\mathrm{MS}^{\mathrm{n}}$ column) are indicated using 
"X" (see Table 2). Tab 6. MA data. Normalized MA species ion counts from LC/MS data. Species amounts in each replicate (rep) are normalized by dividing the total ion counts of individual species by the total ion counts of all detected MA species in the sample. Tab 7. Statistical tests. $P$ values for statistical tests comparing $C$ number and DB number for each lipid class between strains or growth conditions. Statistical significance was determined using a one mean, two-tailed Student's $t$ test with a threshold of significance of $P<0.05$.

\section{Authors' contributions}

GD, TSM, and MF conceived the study. WRH and FFH performed experiments and analyzed data. WRH, FFH, GD, TSM, and MF wrote the manuscript. All authors read and approved the final manuscript.

\section{Author details}

${ }^{1}$ Department of Energy, Environmental and Chemical Engineering, Washington University in St. Louis, St. Louis, MO 63130, USA. ${ }^{2}$ Mass Spectrometry Resource, Division of Endocrinology, Diabetes, Metabolism, and Lipid Research, Department of Internal Medicine, Washington University School of Medicine, St. Louis, MO 63110, USA. ${ }^{3}$ Department of Pathology and Immunology, Washington University in St. Louis School of Medicine, St. Louis, MO 63108, USA. ${ }^{4}$ The Edison Family Center for Genome Sciences and Systems Biology, Washington University in St. Louis School of Medicine, St. Louis, MO 63110, USA. ${ }^{5}$ Department of Biomedical Engineering, Washington University in St. Louis, St. Louis, MO 63130, USA. ${ }^{6}$ Department of Molecular Microbiology, Washington University in St. Louis, St. Louis, MO 63108, USA.

\section{Acknowledgements}

The authors thank Cheryl Frankfater and members of the Moon and Foston research groups for scientific discussions.

\section{Competing interests}

The authors declare that they have no competing interests.

\section{Availability of data and materials}

The datasets used and/or analyzed during the current study are available from the corresponding authors on reasonable request.

\section{Consent for publication}

Not applicable.

\section{Ethics approval and consent to participate}

Not applicable.

\section{Funding}

U.S. Department of Energy [DE-SC0012705 and DE-SC0018324 to G.D., T.S.M., and M.F.], National Institutes of Health [P41-GM103422, P60-DK-20579, P30-DK56341 (Mass Spectrometry Resource) to F.F.H].

\section{Publisher's Note}

Springer Nature remains neutral with regard to jurisdictional claims in published maps and institutional affiliations.

\section{Received: 29 April 2018 Accepted: 11 December 2018}

\section{Published online: 28 December 2018}

\section{References}

1. Bozell JJ, Petersen GR. Technology development for the production of biobased products from biorefinery carbohydrates-the US Department of Energy's "Top 10" revisited. Green Chem. 2010;12(4):539-54.

2. Hahn-Hagerdal B, Galbe M, Gorwa-Grauslund MF, Liden G, Zacchi G Bio-ethanol - the fuel of tomorrow from the residues of today. Trends Biotechnol. 2006;24(12):549-56.

3. Lynd LR, Liang X, Biddy MJ, Allee A, Cai H, Foust T, Himmel ME, Laser MS, Wang M, Wyman CE. Cellulosic ethanol: status and innovation. Curr Opin Biotechnol. 2017;45:202-11.
4. Sorek N, Yeats TH, Szemenyei H, Youngs H, Somerville CR. The implications of lignocellulosic biomass chemical composition for the production of advanced biofuels. Bioscience. 2014;64(3):192-201.

5. Li Y, Tschaplinski TJ, Engle NL, Hamilton CY, Rodriguez M Jr, Liao JC, Schadt CW, Guss AM, Yang Y, Graham DE. Combined inactivation of the Clostridium cellulolyticum lactate and malate dehydrogenase genes substantially increases ethanol yield from cellulose and switchgrass fermentations. Biotechnol Biofuels. 2012;5(1):2.

6. Schwartz C, Frogue K, Misa J, Wheeldon I. Host and pathway engineering for enhanced lycopene biosynthesis in Yarrowia lipolytica. Front Microbiol. 2017;8:2233.

7. Boerjan W, Ralph J, Baucher M. Lignin biosynthesis. Annu Rev Plant Biol. 2003;54:519-46.

8. Studer MH, DeMartini JD, Davis MF, Sykes RW, Davison B, Keller M, Tuskan GA, Wyman CE. Lignin content in natural Populus variants affects sugar release. Proc Natl Acad Sci USA. 2011;108(15):6300-5.

9. Linger JG, Vardon DR, Guarnieri MT, Karp EM, Hunsinger GB, Franden MA, Johnson CW, Chupka G, Strathmann TJ, Pienkos PT, et al. Lignin valorization through integrated biological funneling and chemical catalysis. Proc Natl Acad Sci USA. 2014;111(33):12013-8.

10. Beckham GT, Johnson CW, Karp EM, Salvachua D, Vardon DR. Opportunities and challenges in biological lignin valorization. Curr Opin Biotechnol. 2016;42:40-53.

11. Wheeldon I, Christopher P, Blanch H. Integration of heterogeneous and biochemical catalysis for production of fuels and chemicals from biomass. Curr Opin Biotechnol. 2017;45:127-35.

12. Xie S, Sun Q, Pu Y, Lin F, Sun S, Wang X, Ragauskas AJ, Yuan JS. Advanced chemical design for efficient lignin bioconversion. ACS Sustain Chem Eng. 2017;5(3):2215-23.

13. Uppugundla N, da Costa Sousa L, Chundawat SP, Yu X, Simmons B, Singh S, Gao X, Kumar R, Wyman CE, Dale BE, et al. A comparative study of ethanol production using dilute acid, ionic liquid and AFEX pretreated corn stover. Biotechnol Biofuels. 2014;7:72.

14. Chen B, Ling H, Chang MW. Transporter engineering for improved tolerance against alkane biofuels in Saccharomyces cerevisiae. Biotechnol Biofuels. 2013;6(1):21.

15. Ling H, Teo W, Chen B, Leong SS, Chang MW. Microbial tolerance engineering toward biochemical production: from lignocellulose to products. Curr Opin Biotechnol. 2014;29:99-106.

16. Clarkson SM, Giannone RJ, Kridelbaugh DM, Elkins JG, Guss AM, Michener JK. Construction and optimization of a heterologous pathway for protocatechuate catabolism in Escherichia coli enables bioconversion of model aromatic compounds. Appl Environ Microbiol. 2017;83(18):e01313-7.

17. Liu ZH, Xie S, Lin F, Jin M, Yuan JS. Combinatorial pretreatment and fermentation optimization enabled a record yield on lignin bioconversion. Biotechnol Biofuels. 2018;11:21.

18. Jarboe $L R$, Liu P, Royce LA. Engineering inhibitor tolerance for the production of biorenewable fuels and chemicals. Curr Opin Chem Eng. 2011;1(1):38-42.

19. Kosa M, Ragauskas AJ. Bioconversion of lignin model compounds with oleaginous Rhodococci. Appl Microbiol Biotechnol. 2012;93(2):891-900.

20. Yoneda A, Henson WR, Goldner NK, Park KJ, Forsberg KJ, Kim SJ, Pesesky MW, Foston M, Dantas G, Moon TS. Comparative transcriptomics elucidates adaptive phenol tolerance and utilization in lipid-accumulating Rhodococcus opacus PD630. Nucleic Acids Res. 2016;44(5):2240-54.

21. Kurosawa K, Plassmeier J, Kalinowski J, Ruckert C, Sinskey AJ. Engineering L-arabinose metabolism in triacylglycerol-producing Rhodococcus opacus for lignocellulosic fuel production. Metab Eng. 2015;30:89-95.

22. Kurosawa K, Wewetzer SJ, Sinskey AJ. Engineering xylose metabolism in triacylglycerol-producing Rhodococcus opacus for lignocellulosic fuel production. Biotechnol Biofuels. 2013;6(1):134.

23. Le RK, Wells T Jr, Das P, Meng X, Stoklosa RJ, Bhalla A, Hodge DB, Yuan JS, Ragauskas AJ. Conversion of corn stover alkaline pre-treatment waste streams into biodiesel via Rhodococci. RSC Adv. 2017;7(7):4108-15.

24. Hollinshead WD, Henson WR, Abernathy M, Moon TS, Tang YJ. Rapid metabolic analysis of Rhodococcus opacus PD630 via parallel ${ }^{13} \mathrm{C}$-metabolite fingerprinting. Biotechnol Bioeng. 2016;113(1):91-100

25. Alvarez HM, Mayer F, Fabritius D, Steinbuchel A. Formation of intracytoplasmic lipid inclusions by Rhodococcus opacus strain PD630. Arch Microbiol. 1996;165(6):377-86. 
26. DeLorenzo DM, Rottinghaus AG, Henson WR, Moon TS. Molecular toolkit for gene expression control and genome modification in Rhodococcus opacus PD630. ACS Synth Biol. 2018;7(2):727-38.

27. DeLorenzo DM, Henson WR, Moon TS. Development of chemical and metabolite sensors for Rhodococcus opacus PD630. ACS Synth Biol. 2017;6(10):1973-8.

28. DeLorenzo DM, Moon TS. Selection of stable reference genes for RTqPCR in Rhodococcus opacus PD630. Sci Rep. 2018;8(1):6019.

29. Alvarez HM, Kalscheuer R, Steinbuchel A. Accumulation and mobilization of storage lipids by Rhodococcus opacus PD630 and Rhodococcus ruber NCIMB 40126. Appl Microbiol Biotechnol. 2000;54(2):218-23.

30. Chen Y, Ding Y, Yang L, Yu J, Liu G, Wang X, Zhang S, Yu D, Song L, Zhang $\mathrm{H}$, et al. Integrated omics study delineates the dynamics of lipid droplets in Rhodococcus opacus PD630. Nucleic Acids Res. 2014;42(2):1052-64.

31. MacEachran DP, Prophete ME, Sinskey AJ. The Rhodococcus opacus PD630 heparin-binding hemagglutinin homolog TadA mediates lipid body formation. Appl Environ Microbiol. 2010;76(21):7217-25.

32. Holder JW, Ulrich JC, DeBono AC, Godfrey PA, Desjardins CA, Zucker J, Zeng Q, Leach AL, Ghiviriga I, Dancel C, et al. Comparative and functional genomics of Rhodococcus opacus PD630 for biofuels development. PLoS Genet. 2011;7(9):e1002219.

33. Royce LA, Liu P, Stebbins MJ, Hanson BC, Jarboe LR. The damaging effects of short chain fatty acids on Escherichia coli membranes. Appl Microbiol Biotechnol. 2013;97(18):8317-27.

34. Liu P, Chernyshov A, Najdi T, Fu Y, Dickerson J, Sandmeyer S, Jarboe L. Membrane stress caused by octanoic acid in Saccharomyces cerevisiae. Appl Microbiol Biotechnol. 2013;97(7):3239-51.

35. Henderson CM, Block DE. Examining the role of membrane lipid composition in determining the ethanol tolerance of Saccharomyces cerevisiae. Appl Environ Microbiol. 2014;80(10):2966-72.

36. Xia JM, Yuan YJ. Comparative lipidomics of four strains of Saccharomyces cerevisiae reveals different responses to furfural, phenol, and acetic acid. J Agric Food Chem. 2009;57(1):99-108.

37. Lindberg L, Santos AX, Riezman H, Olsson L, Bettiga M. Lipidomic profiling of Saccharomyces cerevisiae and Zygosaccharomyces bailii reveals critical changes in lipid composition in response to acetic acid stress. PLoS ONE. 2013;8(9):e73936.

38. Rodriguez-Vargas S, Sanchez-Garcia A, Martinez-Rivas JM, Prieto JA, Randez-Gil F. Fluidization of membrane lipids enhances the tolerance of Saccharomyces cerevisiae to freezing and salt stress. Appl Environ Microbiol. 2007;73(1):110-6.

39. Bernal P, Segura A, Ramos JL. Compensatory role of the cis-transisomerase and cardiolipin synthase in the membrane fluidity of Pseudomonas putida DOT-T1E. Environ Microbiol. 2007;9(7):1658-64.

40. Pinkart HC, White DC. Phospholipid biosynthesis and solvent tolerance in Pseudomonas putida strains. J Bacteriol. 1997;179(13):4219-26.

41. Pini CV, Bernal P, Godoy P, Ramos JL, Segura A. Cyclopropane fatty acids are involved in organic solvent tolerance but not in acid stress resistance in Pseudomonas putida DOT-T1E. Microb Biotechnol. 2009;2(2):253-61.

42. Sutcliffe IC. Cell envelope composition and organisation in the genus Rhodococcus. Antonie Van Leeuwenhoek. 1998;74(1-3):49-58.

43. Minnikin DE. Chemical principles in the organization of lipid components in the mycobacterial cell envelope. Res Microbiol. 1991;142(4):423-7.

44. Hoffmann C, Leis A, Niederweis M, Plitzko JM, Engelhardt H. Disclosure of the mycobacterial outer membrane: cryo-electron tomography and vitreous sections reveal the lipid bilayer structure. Proc Natl Acad Sci USA. 2008;105(10):3963-7.

45. Gebhardt H, Meniche X, Tropis M, Kramer R, Daffe M, Morbach S. The key role of the mycolic acid content in the functionality of the cell wall permeability barrier in Corynebacterineae. Microbiology. 2007:153(5):1424-34

46. Bansal-Mutalik R, Nikaido H. Quantitative lipid composition of cell envelopes of Corynebacterium glutamicum elucidated through reverse micelle extraction. Proc Natl Acad Sci USA. 2011;108(37):15360-5.
47. Bansal-Mutalik R, Nikaido H. Mycobacterial outer membrane is a lipid bilayer and the inner membrane is unusually rich in diacyl phosphatidylinositol dimannosides. Proc Natl Acad Sci USA. 2014;111(13):4958-63.

48. de Carvalho CC, Fatal V, Alves SS, da Fonseca MM. Adaptation of Rhodococcus erythropolis cells to high concentrations of toluene. Appl Microbiol Biotechnol. 2007;76(6):1423-30.

49. Tsitko IV, Zaitsev GM, Lobanok AG, Salkinoja-Salonen MS. Effect of aromatic compounds on cellular fatty acid composition of Rhodococcus opacus. Appl Environ Microbiol. 1999;65(2):853-5.

50. Hsu FF, Soehl K, Turk J, Haas A. Characterization of mycolic acids from the pathogen Rhodococcus equi by tandem mass spectrometry with electrospray ionization. Anal Biochem. 2011;409(1):112-22.

51. Kolouchova I, Schreiberova O, Masak J, Sigler K, Rezanka T. Structural analysis of mycolic acids from phenol-degrading strain of Rhodococcus erythropolis by liquid chromatography-tandem mass spectrometry. Folia Microbiol (Praha). 2012;57(6):473-83.

52. de Carvalho CC, Fischer MA, Kirsten S, Wurz B, Wick LY, Heipieper HJ. Adaptive response of Rhodococcus opacus PWD4 to salt and phenolic stress on the level of mycolic acids. AMB Express. 2016;6(1):66.

53. Kurosawa K, Boccazzi P, de Almeida NM, Sinskey AJ. High-cell-density batch fermentation of Rhodococcus opacus PD630 using a high glucose concentration for triacylglycerol production. J Biotechnol. 2010;147(3-4):212-8.

54. Zhang YM, Rock CO. Membrane lipid homeostasis in bacteria. Nat Rev Microbiol. 2008;6(3):222-33.

55. Gosselink RJ, Teunissen W, van Dam JE, de Jong E, Gellerstedt G, Scott EL, Sanders JP. Lignin depolymerisation in supercritical carbon dioxide/ acetone/water fluid for the production of aromatic chemicals. Bioresour Technol. 2012;106:173-7.

56. Lavoie J-M, Baré W, Bilodeau M. Depolymerization of steam-treated lignin for the production of green chemicals. Bioresour Technol. 2011;102(7):4917-20.

57. Jiang Z, Ting H, Li J, Hu C. Selective conversion of lignin in corncob residue to monophenols with high yield and selectivity. Green Chem. 2014;16:4257-65.

58. Sikkema J, de Bont JA, Poolman B. Mechanisms of membrane toxicity of hydrocarbons. Microbiol Rev. 1995;59(2):201-22.

59. Kurosawa K, Laser J, Sinskey AJ. Tolerance and adaptive evolution of triacylglycerol-producing Rhodococcus opacus to lignocellulosederived inhibitors. Biotechnol Biofuels. 2015;8:76.

60. Bligh EG, Dyer WJ. A rapid method of total lipid extraction and purification. Can J Biochem Physiol. 1959;37(8):911-7.

61. Bodennec J, Koul O, Aguado I, Brichon G, Zwingelstein G, Portoukalian J. A procedure for fractionation of sphingolipid classes by solid-phase extraction on aminopropyl cartridges. J Lipid Res. 2000;41 (9):1524-31.

62. Jackson M, Crick DC, Brennan PJ. Phosphatidylinositol is an essential phospholipid of mycobacteria. J Biol Chem. 2000;275(39):30092-9.

63. Nishiuchi Y, Baba T, Yano I. Mycolic acids from Rhodococcus, Gordonia, and Dietzia. J Microbiol Methods. 2000;40(1):1-9.

64. Liu J, Barry CE 3rd, Besra GS, Nikaido H. Mycolic acid structure determines the fluidity of the mycobacterial cell wall. J Biol Chem. 1996:271(47):29545-51.

65. Stanley SA, Kawate T, Iwase N, Shimizu M, Clatworthy AE, Kazyanskaya E, Sacchettini JC, loerger TR, Siddiqi NA, Minami S, et al. Diarylcoumarins inhibit mycolic acid biosynthesis and kill Mycobacterium tuberculosis by targeting FadD32. Proc Natl Acad Sci USA. 2013;110(28):11565-70.

66. Brown GR, Sutcliffe IC, Bendell D, Cummings SP. The modification of the membrane of Oceanomonas baumannii when subjected to both osmotic and organic solvent stress. FEMS Microbiol Lett. 2000;189(2):149-54.

67. Ruhl J, Hein EM, Hayen H, Schmid A, Blank LM. The glycerophospholipid inventory of Pseudomonas putida is conserved between strains and enables growth condition-related alterations. Microb Biotechnol. 2012;5(1):45-58.

68. Chi Z, Kohlwein SD, Paltauf F. Role of phosphatidylinositol (PI) in ethanol production and ethanol tolerance by a high ethanol producing yeast. J Ind Microbiol Biotechnol. 1999;22(1):58-63. 
69. Morita YS, Fukuda T, Sena CB, Yamaryo-Botte Y, McConville MJ, Kinoshita T. Inositol lipid metabolism in mycobacteria: biosynthesis and regulatory mechanisms. Biochim Biophys Acta. 2011;1810(6):630-41.

70. Tan Z, Khakbaz P, Chen Y, Lombardo J, Yoon JM, Shanks JV, Klauda JB, Jarboe LR. Engineering Escherichia coli membrane phospholipid head distribution improves tolerance and production of biorenewables. Metab Eng. 2017;44:1-12
71. Budin I, de Rond T, Chen Y, Chan LJG, Petzold CJ, Keasling JD. Viscous control of cellular respiration by membrane lipid composition. Science. 2018;362:1186-9.

72. Harwood CS, Parales RE. The beta-ketoadipate pathway and the biology of self-identity. Annu Rev Microbiol. 1996;50:553-90.
Ready to submit your research? Choose BMC and benefit from:

- fast, convenient online submission

- thorough peer review by experienced researchers in your field

- rapid publication on acceptance

- support for research data, including large and complex data types

- gold Open Access which fosters wider collaboration and increased citations

- maximum visibility for your research: over $100 \mathrm{M}$ website views per year

At BMC, research is always in progress.

Learn more biomedcentral.com/submissions 